\title{
The Role of Fe(III) Bioreduction by Methanogens in the Preservation of Organic Matter in Smectite
}

\author{
Jing Zhang, ${ }^{\mathrm{a}, \mathrm{b}}$ Hailiang Dong, ${ }^{\mathrm{a}, \mathrm{b}} *$ Qiang Zeng ${ }^{\mathrm{b}}$, and Abinash Agrawal ${ }^{\mathrm{c}}$ \\ ${ }^{a}$ Key Laboratory of Biogeology and Environmental Geology, China University of Geosciences, \\ Beijing 100083, P. R. China \\ ${ }^{\mathrm{b}}$ Department of Geology and Environmental Earth Science \\ Miami University, Ohio 45056, USA \\ ${ }^{\mathrm{c}}$ Department of Earth and Environmental Sciences \\ Wright State University, Ohio 45435, USA
}

Authors to whom correspondence should be addressed (dongh@ miamioh.edu)

Revised for Chemical Geology

September 7, 2014 


\section{ABSTRACT}

Organic matter in sediments is largely associated with clay minerals and can be preserved over geological time. However, microbial activity can possibly influence this association and release organic matter from clay minerals via reductive or oxidative dissolution of clay minerals. In this study, the relationship between bioreduction of structural $\mathrm{Fe}(\mathrm{III})$ in smectite and organic matter release from smectite structure was investigated. A model organic compound, 12-aminolauric acid (ALA) was intercalated into the interlayer region of an iron-rich smectite (nontronite, NAu-2). Two methanogens: mesophilic Methanosarcina mazei and thermophilic Methanothermobacter thermautotrophicus were selected to reduce structural Fe(III) in ALA-intercalated nontronite. As a comparison, sodium dithionite was used to chemically reduce structural $\mathrm{Fe}(\mathrm{III})$ in the same mineral. The results showed that the intercalation of ALA into the nontronite interlayer decreased both the rate and the extent of $\mathrm{Fe}(\mathrm{III})$ bioreduction. Furthermore, methanogenesis was more inhibited by the presence of intercalated ALA in the nontronite structure relative to pure nontronite. After the bioreduction, the intercalated ALA was partially released, and the extent of release was positively correlated with the extent of Fe(III) reduction. A low reduction extent of bioreduction $(<30 \%)$ resulted in little ALA release, whereas a nearly complete chemical reduction by sodium dithionite released all intercalated ALA. SEM observations and aqueous chemistry data suggested that reductive dissolution was a main mechanism for the observed ALA release. Because naturally prevalent biological reduction is a slow process with a low reduction extent relative to chemical reduction, the 
results of this study demonstrated that organic matter preserved within smectite structure should not be released by the mechanism of iron reduction.

Key words: methanogen, iron reduction, organic matter, intercalation, nontronite 


\section{INTRODUCTION}

2 Organic matter burial in sediments results in a rise in the oxygen level in the

3 atmosphere, lowers the atmospheric $\mathrm{CO}_{2}$ level, and thus decreases the temperature of the

4 Earth's surface (Beckmann et al., 2005; Rabalais et al., 2009; Negri et al., 2009; Jenkyns,

5 2003; Lutzow et al., 2006). In contrast, organic matter release from sediments and

6 subsequent oxidation consumes oxygen and increases the $\mathrm{CO}_{2}$ level in the atmosphere

7 (Kennedy and Wagner, 2011). Organic matter preservation in sediments also has

8 important implications for petroleum generation (Bennett, et al., 2013).

9 Most organic matter in aquatic sediments is associated with minerals, especially fine-

10 grained clay minerals, due to their high surface area and strong adsorption capacity

11 (Mayer et al., 1985; Mayer, 1994; Keil et al., 1994; Ransom et al., 1998; Mayer and Xing,

12 2001; Arnarson and Keil, 2001; Kennedy et al., 2002; Galy et al.; 2007). In clay-rich

13 sediments, organic matter abundance is found to positively correlate with smectite

14 abundance (Kennedy et al., 2002; Huguet, et al., 2008). This correlation suggests that the

15 expandable internal surface of smectite (i.e., interlayer region) can sequester large

16 amounts of organic matter (Kennedy and Wagner, 2011). Indeed, it has been suggested

17 that enhanced organic matter preservation in sediments is largely due to increased

18 smectite abundance in sedimentary record through geological time (Kennedy et al., 2006).

19 This organic matter preservation within expandable smectite has been postulated to lead

20 to subsequent cooling of the earth surface temperature and emergence and evolution of

21 macro-biota at the Precambrian/Cambrian boundary (Kennedy et al., 2006). One

22 assumption inherent in this model is that organic matter, once associated with smectite-

23 rich sediments, is physically protected against microbial oxidation. However, it is now 
24 well-known that microbial activities can dissolve clay minerals via reduction of structural

$25 \mathrm{Fe}(\mathrm{III})$; oxidation of structural Fe(II); or pH change (Weber et al., 2006; Dong et al.,

26 2009). All these activities can possibly release organic matter from clay minerals, but

27 these effects have not been directly examined.

28 Iron redox cycling represents a potential mechanism to release organic matter from

29 clay minerals. Iron, as the fourth most abundant element in the earth crust, is ubiquitous

30 in clay-rich soils, sediments, and sedimentary rocks (Stucki and Kostka, 2006; Dong et

31 al., 2009; Dong, 2012). Structural Fe(III) in clay minerals can be reduced either

32 chemically or biologically (Stucki and Kostka, 2006; Dong et al., 2009). Chemically,

33 hydrazine and dithionite are common reductants for Fe(III) (Rozenson and Heller-Kallai,

34 1976; Stucki et al. 1984; Lee et al., 2006). Biologically, since the isolation of

35 dissimilatory Fe(III) reducing bacteria (DIRB) in 1980s (Lovley and Philips, 1988; Myers

36 and Nealson, 1988), numerous studies have demonstrated that a variety of anaerobic

37 microorganisms are capable of iron reduction in iron-bearing clay minerals, including

38 typical DIRB (Kostka et al., 1996; Lovley et al., 1998; Dong et al., 2003; Zhang et al.,

39 2007a), sulfate-reducing bacteria (Li et al., 2004; Liu et al., 2012), and even methanogens

40 (Liu et al., 2011a; Zhang et al., 2012). The reduction of structural iron in clay minerals

41 can result in important changes in the physical and chemical properties of these minerals,

42 such as layer charge, degree of swelling, and surface area (Stucki, 2011). Reductive

43 dissolution of clay minerals can occur as a result of Fe(III) reduction, especially when the

44 extent of reduction is greater than $30 \%$ (Jaisi et al., 2008; Dong et al., 2009), but the

45 impact of the dissolution on the fate of clay-associated organic matter is unclear.

46 Methanogens are cosmopolitan archaea on both modern and ancient earth, and they 
47 can utilize different types of organic matter to produce $\mathrm{CH}_{4}$. Methanogens can co-exist

48 with clay minerals in a variety of anoxic environments (Achtnich et al., 1995; Van

49 Bodegom and Stams, 1999; Liu et al., 2011a). Recent studies have revealed that certain

50 types of methanogens can reductively dissolve some clay minerals and inhibit methane

51 production (Liu et al., 2011a; Zhang et al., 2012; Zhang et al., 2013). This inhibition is

52 likely due to diversion of electrons from methanogenesis to Fe(III) reduction (Bond and

53 Lovley, 2002; Liu et al., 2011a; Zhang et al., 2012). These studies suggest that clay-

54 bound $\mathrm{Fe}(\mathrm{III})$ as an alternative electron acceptor for methanogens may be an important

55 factor in influencing organic carbon preservation in clay minerals.

56 The objective of this study was to investigate if organic matter could be released from

57 clay minerals by either microbial or chemical reduction of structural Fe(III) in clay

58 minerals. We conducted laboratory experiments to address the following questions: (i)

59 can organic matter that is intercalated in expandable smectite be released by chemical or

60 biological reduction of structural Fe(III)? If so, what are the extents and rates of organic

61 matter release; (ii) does the presence of organic matter in the interlayer of smectite affect

$62 \mathrm{Fe}(\mathrm{III})$ reduction by methanogens; (iii) what is the relationship between iron reduction,

63 organic matter release, and methanogenesis; and (iv) what is the mechanism of organic

64 matter release by methanogens. To address these questions, a model organic compound,

65 12-Aminolauric acid (ALA) was intercalated into the interlayer of an iron-rich smectite,

66 nontronite (ALA-NAu-2). Two methanogens, mesophilic Methanosarcina mazei (optimal

67 growth temperature of $37^{\circ} \mathrm{C}$ ) and thermophilic Methanothermobacter thermautotrophicus

68 (optimum growth temperature of $65^{\circ} \mathrm{C}$ ), were selected to reduce structural $\mathrm{Fe}(\mathrm{III})$ in

69 NAu-2 and ALA-NAu-2. Various geochemical and mineralogical methods were 
employed to examine the reaction progress and to characterize mineralogical

71 transformations. Our results demonstrated that the intercalated ALA in nontronite was

72 largely protected from biological reduction of structural $\mathrm{Fe}(\mathrm{III})$, but chemical reduction

73 by sodium dithionite resulted in a large amount of ALA release through reductive

74 dissolution. The results of this study have important implications for the understanding of

75 the relationship between the preservation of organic matter in clay minerals and iron

76 biogeochemistry.

\section{MATERIALS AND METHODS}

\subsection{Clay mineral preparation}

Nontronite NAu-2 was purchased from the Source Clays Repository of the Clay

81 Minerals Society (West Lafayette, IN) for its high iron content. Our previous study 82 showed that Fe(III) bioreduction was positively correlated with Fe content (Bishop et al., 83 2011). Therefore, this iron-rich smectite represents an extreme case for testing the release 84 of clay-associated organic matter. Previous studies have shown the following formula for 85 NAu-2: $\left(\mathrm{K}_{0.01} \mathrm{Na}_{0.30} \mathrm{Ca}_{0.15}\right)\left(\mathrm{Al}_{0.55} \mathrm{Fe}^{3+}{ }_{3.27} \mathrm{Fe}^{2+}{ }_{0.06} \mathrm{Mg}_{0.12}\right)\left(\mathrm{Si}_{7.57} \mathrm{Al}_{0.15} \mathrm{Fe}^{3+}{ }_{0.28}\right) \mathrm{O}_{20}(\mathrm{OH})_{4} \quad$ (Bishop et

87 al., 2011). The bulk nontronite was manually ground and soaked in a $0.5 \mathrm{~N} \mathrm{NaCl}$ solution overnight followed by centrifugation to separate the $0.02-0.5 \mu \mathrm{m}$ fraction. The chloride

89 anion was completely washed by double distilled water, and its complete removal was

90 confirmed with $\mathrm{AgNO}_{3}$. The BET surface area of the $0.02-0.5 \mu \mathrm{m}$ fraction is $271 \mathrm{~m}^{2} / \mathrm{g}$

91 (Bishop et al., 2011).

92 
12-Aminolauric acid (ALA) $\left[\mathrm{NH}_{2}\left(\mathrm{CH}_{2}\right)_{11} \mathrm{COOH}\right]$ was used as a model organic

compound. This compound has a similar structure as amino acid and was selected in this study for two reasons. First, the intercalation of ALA in smectite interlayer was more stable than amino acid because of its long chain length. There was no release of ALA even after several washes with hot water $\left(>80^{\circ} \mathrm{C}\right)$ This stability was an important consideration for the purpose of examining the effect of Fe(III) reduction on ALA release. Second, our selected methanogens could not use it as a carbon source so that again we could evaluate the effect of Fe(III) reduction on ALA release. ALA was commercially purchased from TCI AMERICA (CAS Number: 693-57-2).

Prior to ALA intercalation into the interlayer region of nontronite, $2 \mathrm{~g}$ of the 0.02 $0.5 \mu \mathrm{m}$ fraction of NAu-2 was placed in a beaker and mechanically stirred in $200 \mathrm{~mL}$ deionized water for several hours until NAu-2 suspension was completely swollen. ALA $(0.6 \mathrm{~g}, 2.8 \mathrm{mmol})$ was pre-treated with $\mathrm{HCl}(0.07 \mathrm{~N} ; \mathrm{pH}=1.14,40 \mathrm{~mL})$ to form protonated ALA followed by addition to the NAu-2 suspension. After vigorously stirring for $30 \mathrm{~min}$ at $80^{\circ} \mathrm{C}$, the resultant ALA-intercalated nontronite NAu-2 (ALA-NAu-2) was collected by centrifugation and washed thoroughly several times with deionized water. The whole procedure was operated under $80^{\circ} \mathrm{C}$ to ensure full dissolution of ALA in water. The intercalation of ALA into the nontronite interlayer was confirmed with X-ray diffraction (XRD), Fourier transform infrared (FTIR) spectroscopy, and total organic carbon (TOC) measurement. Total Fe and Fe(II) contents in NAu-2 and ALA-NAu-2 were measured with the 1,10 phenanthroline method (Amonette and Templeton, 1998). 
Two methanogens, mesophilic M. mazei and thermophilic M. thermautotrophicus

118 were kindly provided by Dr. Xiuzhu Dong (Institute of Microbiology, Chinese Academy 119 of Sciences, Beijing, China). These strains are routinely cultured in a sulfate-free culture 120 medium (revised from Zehnder and Wuhermann, 1977) under strictly anoxic condition. 121 In brief, this medium consists of (per liter) $0.54 \mathrm{~g} \mathrm{KH}_{2} \mathrm{PO}_{4}, 1.33 \mathrm{~g} \mathrm{~K}_{2} \mathrm{HPO}_{4} \cdot 3 \mathrm{H}_{2} \mathrm{O}, 1.8 \mathrm{~g}$ 122 yeast extract, $0.5 \mathrm{~g}$ tryptone, $0.5 \mathrm{~g}$ peptone, $4 \mathrm{~g} \mathrm{NaHCO}_{3}, 0.29 \mathrm{~g} \mathrm{NH} 4 \mathrm{Cl}, 0.096 \mathrm{~g}$ $123 \mathrm{MgCl}_{2} \cdot 6 \mathrm{H}_{2} \mathrm{O}, 0.0096 \mathrm{~g} \mathrm{CaCl}_{2} \cdot 2 \mathrm{H}_{2} \mathrm{O}, 0.29 \mathrm{~g} \mathrm{NaCl}, 1 \mathrm{~mL}$ vitamin solution (Kenealy and 124 Zeikus, 1981), $1 \mathrm{~mL}$ trace mineral solution (Zehnder and Wuhermann, 1977), and $1 \mathrm{~mL}$ $1250.1 \%$ resazurin solution (redox indicator). The medium was made anoxic in serum bottles 126 (100 mL volume) by purging with $\mathrm{O}_{2}$-free $\mathrm{N}_{2} / \mathrm{CO}_{2}(80: 20)$ mix gas and sterilized via 127 autoclaving. Filter-sterilized methanol (final conc. 0.5\%) was added as a substrate to 128 support the growth of M. mazei (Boone and Mah, 1987). In the serum bottles with $M$. 129 thermautotrophicus, filtered $\mathrm{H}_{2} / \mathrm{CO}_{2}(80: 20)$ mix gas was injected into the headspace of 130 the bottles until a pressure of $140 \mathrm{kPa}$ was reached (Zhang et al., 2013). Before cell 131 inoculation, all the serum bottles were stored at $65^{\circ} \mathrm{C}$ overnight to allow the sulfur 132 functional group of yeast extract to react with any residual $\mathrm{O}_{2}$. The final $\mathrm{pH}$ of the 133 medium was adjusted to 7.0 with $0.1 \mathrm{~N} \mathrm{HCl}$. M. mazei and $M$. thermautotrophicus were 134 cultured in this sulfate-free medium at $37^{\circ} \mathrm{C}$ and $65^{\circ} \mathrm{C}$, respectively. They were transferred 135 three times before Fe(III) bioreduction experiments were initiated.

\section{$137 \quad 2.4$ Biological reduction experiments}

138 ALA-NAu-2 (final conc. = $5 \mathrm{~g} / \mathrm{L}$ ) was made into slurry with the sulfate-free 
139 culture medium in serum bottles (total volume, $60 \mathrm{~mL}$ ). Because both $\mathrm{K}$ and $\mathrm{Al}$ are the 140 limiting factors in microbial conversion of smectite to illite (Zhang et al., 2007b), 141 external sources of $\mathrm{K}$ and $\mathrm{Al}$ were needed to promote this reaction. The $\mathrm{K}$ concentration 142 in the sulfate-free culture medium was already adequate $(>20 \mathrm{mM})$. An external $\mathrm{Al}$ source 143 (final conc. $=1 \mathrm{~g} / \mathrm{L}$ ) was provided in the form of amorphous $\mathrm{Al}(\mathrm{OH})_{3} \cdot \mathrm{nH}_{2} \mathrm{O}$ to favor illite 144 formation (Zhang et al., 2007b). The bottles were purged with $\mathrm{N}_{2} / \mathrm{CO}_{2}(80: 20)$, and then 145 sealed with thick butyl rubber stoppers (Chemglass, NJ) and aluminum crimps. After 146 autoclaving, sterilized methanol (final conc. 0.5\%) and $\mathrm{H}_{2} / \mathrm{CO}_{2}(80: 20)$ gas mix were 147 added as substrates into the bottles for M. mazei and M. thermautotrophicus, respectively, 148 and all bottles were stored at $65^{\circ} \mathrm{C}$ overnight to achieve an anoxic condition. The amount 149 of abiotic reduction of $\mathrm{Fe}(\mathrm{III})$ in ALA-NAu-2 by the sulfur functional group of yeast 150 extract in control bottles was negligible in comparison with the amount of $\mathrm{Fe}(\mathrm{III})$ 151 bioreduction (see below) and was subtracted from the measured Fe(II) concentration to 152 quantify the overall Fe(III) bioreduction.

153 M. mazei and M. thermautotrophicus cells in their exponential growth phase were 154 injected into the experimental bottles with a final concentration of $10^{8}$ cells $/ \mathrm{mL}$ based on 155 acridine-orange direct counts (AODC). In selected experiments, $0.1 \mathrm{mM}$ anthraquinone156 2,6-disulfonate (AQDS), a humic acid analog, was supplied as an electron shuttle. There 157 were three control groups in this experiment. Control A group was identical to the 158 experimental bottles except that cells were replaced with an equal amount of culture 159 medium (abiotic control), whereas Control B group was identical to the experimental 160 bottles but without any clay minerals (methanogenesis control). Control C group was 161 identical to the experimental bottles but with NAu-2 slurry instead of ALA-NAu-2 
162 (bioreduction positive control). All treatments were performed in duplicates. All reagents

163 and cultures were transferred using sterile needles and syringes. Experimental bottles

164 with $20 \mathrm{~mL}$ slurry $\left(40 \mathrm{~mL}\right.$ headspace, total $60 \mathrm{~mL}$ volume bottles) were incubated at $37^{\circ} \mathrm{C}$

165 for $M$. mazei, and $65^{\circ} \mathrm{C}$ for $M$. thermautotrophicus.

166

167

168

\subsection{Chemical reduction ALA-NAu-2}

To compare different mechanisms of ALA release from nontronite, we also performed chemical reduction of structural Fe(III) in NAu-2 and ALA-NAu-2 using the dithionite-citrate-bicarbonate (DCB) procedure (Stucki et al., 1984). Chemically reduced NAu-2 and ALA-NAu-2 was separated by centrifugation and washed four times with anoxic deionized water for subsequent characterization.

\subsection{Analytical methods}

\subsubsection{Chemical analyses}

In order to monitor the progress of biological and chemical Fe(III) reductions, total $\mathrm{Fe}(\mathrm{II})$ concentration was measured at selected times by the 1,10 phenanthroline method (Amonette and Templeton, 1998). To monitor the reductive dissolution of NAu-2 and ALA-NAu-2, aqueous concentrations of $\mathrm{Fe}, \mathrm{Al}$, and $\mathrm{Si}$ were measured at the end of the experiments. Aqueous suspension of $3 \mathrm{~mL}$ in volume was sampled and centrifuged inside an anaerobic glove box (Coy Laboratory Products, Grass Lake, MI, USA) to collect supernatants followed by concentration measurements with inductively coupled plasma optical emission spectrophotometry (ICP-OES) (Agilent Technologies 700 Series). At the beginning and end of the experiments, $\mathrm{pH}$ values were measured inside a glove box with a pH meter (Accumet ${ }^{\circledR} \mathrm{AB} 15$, Cole-Parmer). 
Time course $\mathrm{CH}_{4}$ production was monitored to evaluate any effect of bioreduction

189 on methanogenesis. At a given time point, $1 \mathrm{~mL}$ headspace gas was collected from the

190 experimental bottles and analyzed for $\mathrm{CH}_{4}$ amount with a Hewlett-Packard 6890 series

191 gas chromatography system on a capillary column (GS GasPro, $30 \mathrm{~m} \times 0.32 \mathrm{~mm}$; J\&W

192 Scientific, Folsom, CA) that is connected to a flame ionization detector. Based on

193 measured partial pressure of $\mathrm{CH}_{4}$ in the headspace of experimental and control bottles,

194 the total amount of $\mathrm{CH}_{4}$ in both gas and liquid phases was calculated by the Ideal Gas

195 Law and Henry's law using their respective Henry's constants (where $\mathrm{K}_{\mathrm{H}}$ for $\mathrm{CH}_{4}$ at

$19625^{\circ} \mathrm{C}=1.51 \times 10^{-3} \mathrm{~mol} \mathrm{~L}^{-1} \mathrm{~atm}^{-1}$, Schwarzenbach et al., 1995).

198 2.4.3 Total organic carbon (TOC) measurement

199 In order to monitor the change of ALA content in ALA-NAu-2 throughout the

$200 \mathrm{Fe}(\mathrm{III})$ reduction experiments, at selected time points, $2 \mathrm{~mL}$ of cell-clay suspension were 201 taken from the experimental bottles inside an anaerobic glove box and washed with DI 202 water three times to remove any interfering organic components from the medium 203 (peptone, tryptone, and yeast extract). After drying, about $10 \mathrm{mg}$ of dried ALA-NAu-2 204 was wrapped in tin capsule and analyzed with a Flash 2000 NC Soil Analyzer (CE 205 Elantech) to determine TOC content. 
209 comparing XRD patterns of unreduced and reduced NAu-2 and ALA-NAu-2. Clay

210 slurries were sampled with a syringe needle and smeared (Moore and Reynolds, 1997)

211 onto petrographic slides and dried at $30^{\circ} \mathrm{C}$ overnight in a glove box. XRD patterns were

212 collected on both untreated samples and those solvated with ethylene glycol (EG) vapor

213 at $60^{\circ} \mathrm{C}$ overnight (Moore and Reynolds, 1997) to expand nontronite interlayers. The

214 same slides were subsequently placed in a desiccator at room temperature for 24 hrs to

215 allow further time for EG vapor to penetrate into the nontronite interlayer. XRD patterns

216 were obtained immediately after saturation without significant exposure to air in a

217 humidity-controlled laboratory. Powder XRD patterns were collected by a Scintag X-ray

218 powder diffractometer using $\mathrm{CuK} \alpha$ radiation, a fixed slit scintillation detector, and power

219 of $1,400 \mathrm{~W}(40 \mathrm{kV}, 35 \mathrm{~mA})$. XRD slides were scanned in 0.02 two-theta steps with a

220 count time of $2 \mathrm{~s}$ per step and a scanning range of $2^{\circ}$ to $70^{\circ}$ two-theta.

FTIR spectroscopy was used to confirm intercalation of ALA into the expandable 224 interlayer of nontronite NAu-2 and to assess any structural changes of NAu-2 and ALA$225 \mathrm{NAu}-2$ after $\mathrm{Fe}(\mathrm{III})$ reduction. For this analysis, $200 \mathrm{mg}$ of $\mathrm{KBr}$ and $2 \mathrm{mg}$ of sample 226 powder were weighed, mixed, and ground to fully disperse NAu-2 and ALA-NAu-2 227 samples in $\mathrm{KBr}$. The samples were analyzed in the diffuse reflectance mode using a 228 Perkin-Elmer Frontier Infrared Spectrometer. Fifty scans over the range $400-4000 \mathrm{~cm}^{-1}$ 229 with a spectral resolution of $4 \mathrm{~cm}^{-1}$ were accumulated for each spectrum. 
233 NAu-2 were further characterized by using SEM. Clay suspension $(0.5 \mathrm{ml})$ was mounted

234 on a $15 \mathrm{~mm}$ cover slip pretreated with poly-L-lysine for $15 \mathrm{~min}$. The sample-coated cover

235 slip was sequentially dehydrated using varying proportions of ethanol followed by critical 236 point drying with a Tousimis Samdro-780A Critical Point Dryer (CPD) (Dong et al., 237 2003). The sample-coated cover slip was mounted on SEM stub via clear double-sided 238 sticky tape and coated with a Denton Desk II Gold Sputter Coater for SEM observations. 239 The samples were analyzed with a Zeiss Supra 35 VP SEM with Genesis 2000 X-ray 240 energy dispersive spectroscopy (SEM/EDS). The EDS provided a primary means for 241 mineralogical identification. The SEM was operated at an accelerating voltage of 3 to 20 $242 \mathrm{kV}$. A short working distance $(6-10 \mathrm{~mm})$ and low beam current $(30-40 \mu \mathrm{A})$ were used to 243 achieve the best image resolution. A certain working distance $(8.5 \mathrm{~mm})$ and higher beam 244 current $(50-70 \mu \mathrm{A})$ were used for qualitative EDS.

\section{3. RESULTS}

\subsection{Characterization of ALA-NAu-2}

The amount of ALA intercalated into the NAu-2 interlayer was 8.5\% (wt. \%). The

249 total Fe content was $22 \%$ (wt. \%) in the $0.02-0.5 \mu$ m size fraction of NAu-2, of which $2 \%$

250 was $\mathrm{Fe}(\mathrm{II})$; whereas the total Fe content decreased to $19 \%$ for the same size fraction of 251 ALA-NAu-2, of which $2 \%$ was Fe(II).

252 The increase in the $\mathrm{d}(001)$ spacing from $12.18 \AA$ for $\mathrm{NAu}-2$ to $16.65 \AA$ for $\mathrm{ALA}$ 253 NAu-2 confirmed that ALA was intercalated into the interlayer of the NAu-2 structure 
254 (Fig. 1A). Intercalation of ALA into NAu-2 caused significant changes to the FTIR 255 spectrum of NAu-2 (Fig. 1B) (Liu et al., 2011b). In comparison with ALA and NAu-2, 256 ALA intercalation into the NAu-2 interlayer resulted in characteristic absorption bands in 257 the $1700-1300 \mathrm{~cm}^{-1}$ and $3500-2500 \mathrm{~cm}^{-1}$ wave number regions (Fig. 1B). In particular, a 258 broad band from 3500 to $3100 \mathrm{~cm}^{-1}$ was assigned to $\delta \mathrm{NH}_{3}{ }^{+}$deformation, along with an 259 intense band at $1629 \mathrm{~cm}^{-1}$ due to $\delta \mathrm{NH}_{3}{ }^{+}$deformation and $\mathrm{v}_{\mathrm{as}} \mathrm{COO}^{-}$asymmetrical 260 stretching from ALA (Brigatti et al., 1999; Barth, 2000; Liu et al., 2011b). The absorption 261 band at $2918 \mathrm{~cm}^{-1}$ was assigned to $\mathrm{vCH}_{2}$ stretching. Finally, vibration bands at 1406 and $2621385 \mathrm{~cm}^{-1}$ were assigned to $v_{\mathrm{s}} \mathrm{COO}^{-}$and $\delta \mathrm{CH}_{2}$, respectively (Barth, 2000).

\subsection{Microbial reduction of Fe(III) in clay minerals}

Both mesophilic and thermophilic methanogens were able to reduce structural $266 \mathrm{Fe}(\mathrm{III})$ in ALA-NAu-2 but with different rates and extents (Fig. 2). In general, the 267 bioreduction experiments were complete in 4-10 days (depending on specific methanogen 268 strain), but our experiments continued until 30 days to ensure the completion of 269 bioreduction. There was a small amount of abiotic reduction of structural Fe(III) by the 270 sulfur functional group of yeast extract $(<1 \%)$. Thus, this amount, along with the initial 271 amount of $\mathrm{Fe}(\mathrm{II})$ present in the unreduced NAu-2 and ALA-NAu-2, was subtracted from 272 measured $\mathrm{Fe}(\mathrm{II})$ concentration when the final reduction extent was calculated. The $\mathrm{pH}$ in 273 the experimental bottles ranged from 6.5 to 7.2 over the course of the experiments.

274 In the $M$. mazei experiments, the rate of $\mathrm{Fe}(\mathrm{III})$ bioreduction was rapid in the first 2752 days but gradually decreased over time (Fig. 2A \& B). Intercalation of ALA into the 
276 NAu-2 interlayer decreased the initial rate of Fe(III) bioreduction. For example, the initial 277 rate for ALA-NAu-2, calculated for the first $24 \mathrm{hrs}$, was $0.04 \mathrm{mM} / \mathrm{hr}$ without AQDS 278 (open squares in Fig. 2A) and $0.10 \mathrm{mM} / \mathrm{hr}$ with AQDS (solid squares in Fig. 2A). In 279 contrast, the initial rate for pure NAu-2, calculated over the same time duration, was 0.09 $280 \mathrm{mM} / \mathrm{hr}$ and $0.16 \mathrm{mM} / \mathrm{hr}$ without and with AQDS amendments, respectively (Fig. 2B). 281 Intercalation of ALA into the NAu-2 interlayer also lowered the final extent of 282 bioreduction. In the absence of AQDS, the extent decreased from $21.6 \%$ for NAu-2 (open 283 diamonds in Fig. 2B) to $16.8 \%$ for ALA-NAu-2 (open squares in Fig. 2A). With AQDS, 284 the extent decreased from $28.1 \%$ for NAu-2 (solid diamonds in Fig. 2B) to $27.8 \%$ for 285 ALA-NAu-2 (solid squares in Fig. 2A). Again AQDS stimulated Fe(III) reduction, 286 consistent with previous research results (Liu et al., 2011a; Zhang et al., 2012).

287 Similar to the results with $M$. mazei, the rates of bioreduction by $M$. 288 thermautotrophicus were moderately fast in the first 4 days for both the NAu-2 and ALA289 NAu-2 experimental systems (Fig. 2C \& D). After this initial time period, the 290 bioreduction pattern differed between ALA-NAu-2 and NAu-2. For ALA-NAu-2, the rate 291 of bioreduction decreased after day 4 and reached nearly zero after day 10 (Fig. 2C). 292 However, the bioreduction rate for NAu-2 suddenly declined between day 4-7, increased 293 afterwards, and finally reached zero after day 15 (Fig. 2D).

294 Similar to the mesophilic methanogen experiment, ALA intercalation into NAu-2 295 lowered initial bioreduction rate (in the first $24 \mathrm{hrs}$ ) by M. thermautotrophicus. In the 296 absence of AQDS, the rate decreased from $0.03 \mathrm{mM} / \mathrm{hr}$ for $\mathrm{NAu}-2$ to $0.02 \mathrm{mM} / \mathrm{hr}$ for 297 ALA-NAu-2. In the presence of AQDS, the rate decreased from $0.06 \mathrm{mM} / \mathrm{hr}$ for $\mathrm{NAu}-2$ 298 to $0.03 \mathrm{mM} / \mathrm{hr}$ for ALA-NAu-2. The maximal extents of bioreduction by $M$. 
thermautotrophicus were also lower for ALA-NAu-2 (only reaching 13.5\% and $15.4 \%$ without and with AQDS, respectively, Fig. 2C) than those for NAu-2 (26.6\% and 27.0\%,

301 Fig. 2D). However, unlike the M. mazei system, AQDS showed little enhancement of $302 \mathrm{Fe}(\mathrm{III})$ bioreduction by M. thermautotrophicus.

\subsection{Reductive dissolution of NAu-2 and ALA-NAu-2 as a result of bioreduction}

Aqueous $\mathrm{Si}$ and $\mathrm{Fe}$ concentrations in abiotic controls were negligible (data not shown), but in bioreduced, AQDS-amended NAu-2 and ALA-NAu-2 solutions, these concentrations increased with the increasing bioreduction extent (Fig. 3). The highest extent of reduction (83.0\% and $91.0 \%$ for NAu-2 and ALA-NAu-2, respectively) was only achieved with chemical reduction (see below). In the non-AQDS amended experiments, similar correlations were observed between aqueous $\mathrm{Si}$ and $\mathrm{Fe}$ 311 concentrations and reduction extent (data not shown).

\subsection{TOC release from NAu-2 during bioreduction of $\mathrm{Fe}(\mathrm{III})$}

Time-course release of TOC from the NAu-2 interlayer exhibited a similar pattern

315 for all experiments regardless of methanogen strain used. Because TOC content in pure 316 NAu-2 was only $0.1-0.2 \%$ (data not shown, also from Jaisi et al., 2005), the measured 317 TOC content of $\sim 2 \%$ in the bioreduced NAu-2 should have come from the growth 318 medium and the initial biomass that was added at the beginning of the experiments. 319 Throughout the duration of the experiments with $M$. mazei, TOC content in these NAu-2 320 samples increased by $0.12 \%$ and $0.18 \%$ without and with AQDS amendments, 321 respectively; whereas TOC content increased by $0.05 \%$ in the $M$. thermautotrophicus 
322 experiments for both without- and with-AQDS treatments. These data suggest that the

323 amount of cell growth over the experimental duration was insignificant.

As expected, the amount of TOC in ALA-NAu-2 was much higher ( $8.5 \mathrm{wt} \%)$

325 than in NAu-2. In abiotic control group, the net decrease of TOC content in ALA-NAu-2

326 was $<0.2 \mathrm{wt} \%$ by the end of the experiments (30 days, Fig. 4). In the presence of $M$.

327 mazei, however, TOC content decreased by $1.7 \mathrm{wt} \%$ and $1.8 \mathrm{wt} \%$ without and with

328 AQDS treatments, respectively. In comparison, higher amounts of TOC release were

329 observed for the corresponding thermophilic methanogen experiments (e.g., $2.1 \mathrm{wt} \%$ and

$3302.3 \mathrm{wt} \%$ without and with AQDS, respectively). In particular, the TOC release patterns

331 paralleled the Fe(III) bioreduction patterns (Fig. 2A \& C; Fig. 4), e.g., TOC was released

332 during the active bioreduction period. When bioreduction ceased, ALA release also

333 stopped (after day 2 with M. mazei, and after day 7 with M. thermautotrophicus).

3.4 XRD were incubated under the same conditions for additional 70 days to promote any 338 mineralogical transformations. At the end of 100-day incubation, however, no new 339 mineral products were detected by XRD. The bioreduction of structural Fe(III) in ALA-

340 NAu-2 by $M$. mazei resulted in a decrease of the $\mathrm{d}(001)$ spacing from $16.74 \AA$ to $15.09 \AA$ 341 without AQDS. The AQDS amendment promoted a further decrease of the d(001) 342 spacing, e.g., from $16.74 \AA$ A to $14.18 \AA$ (Fig. 5A). With M. thermautotrophicus, the d(001) 343 spacing decreased from $15.78 \AA$ to $13.18 \AA$ and $13.08 \AA$ without and with AQDS, 344 respectively (Fig. 5B). After the ethylene glycol treatment, the d(001) spacing of ALA- 
345 NAu-2 was expanded to $17 \AA$ for all samples (data not shown).

\section{$347 \quad 3.5$ SEM observations}

SEM images revealed that abiotic NAu-2 and ALA-NAu-2 controls displayed a

349 similar flaky texture (Fig. 6A \& B). EDS spectra showed a typical nontronite composition

350 for both NAu-2 and ALA-NAu-2 but with a higher amount of carbon in ALA-NAu-2 (Fig.

$3516 \mathrm{D} \& \mathrm{E})$. After the bioreduction, there were at least two types of clay textures in both the

352 M. mazei and $M$. thermautotrophicus ALA-NAu-2 experimental systems: abundant rose-

353 like flakes (Fig. 6C) and platy particles (Fig. 6G). In comparison with their abiotic

354 controls, the rose-like bioreduced ALA-NAu-2 showed decreased Fe and C contents but

355 with an increased K content (Fig. 6F). The elemental composition of most plate-shaped,

356 bioreduced ALA-NAu-2 (Fig. 6I) exhibited a higher Al/Si ratio and a higher K content

357 than in abiotic controls (Fig. 6E), but the Fe and $\mathrm{C}$ peak heights appeared to be similar to

358 those in abiotic controls. A small amount of silica aggregates was observed in bioreduced

359 ALA-NAu-2 (Figs. 6G and 6J).

\subsection{Methane production}

362 In the absence of clay minerals, there was a significant amount of methane

363 production with time in both the $M$. mazei and $M$. thermautotrophicus experimental 364 systems, similar to previous observations (van Bodegom et al., 2004; Liu et al., 2011a). $365 M$. thermautotrophicus growing on $\mathrm{H}_{2} / \mathrm{CO}_{2}$ produced slightly more methane than $M$. 366 mazei growing on methanol (Fig. 7). However, the addition of NAu-2 into the M. mazei 367 and $M$. thermautotrophicus experimental systems almost completely inhibited methane 
368 production during active Fe(III) reduction periods (e.g., the first 5-7 days, Fig. 2).

369 Methanogenesis resumed in all experimental groups after Fe(III) bioreduction ended.

370 Intercalation of ALA into the nontronite interlayer resulted in lower amounts of methane

371 production especially in $M$. thermautotrophicus systems (Fig. 7B).

372

\section{$373 \quad 3.7$ FTIR}

After the bioreduction of $\mathrm{Fe}(\mathrm{III})$ in ALA-NAu-2, the ALA-specific absorption 375 bands did not change their positions but exhibited slightly lower intensities (Fig. 8A\&B).

376 Similarly, bioreduction resulted in lower intensities of NAu-2 -specific absorption bands

377 in both bioreduced ALA-NAu-2 (Fig. 8C-E) and NAu-2 (Fig. 8F-H). In general, the IR

378 spectrum of nontronite NAu-2 can be broken down into three main regions spanning 379 from 4000 to 400 wavenumbers $\left(\mathrm{cm}^{-1}\right)$, i.e., $3800-3200,1200-950$, and $950-700 \mathrm{~cm}^{-1}$ 380 (Morrison et al., 2013). The spectrum region from $3800 \mathrm{~cm}^{-1}$ to $3200 \mathrm{~cm}^{-1}$ is 381 characterized by the $v \mathrm{M}-\mathrm{OH}$ stretching bands $(\mathrm{M}=\mathrm{Mg}, \mathrm{Al}$ or $\mathrm{Fe}$ in the octahedral layer $)$ 382 (Fialips et al., 2002; Gates, 2005). In this study, the overall position of the OH-stretching 383 band shifted from $3426 \mathrm{~cm}^{-1}$ to $3451 \mathrm{~cm}^{-1}$ after bioreduction of Fe(III) in ALA-NAu-2 384 (Fig. 8C), but this peak did not shift its position after bioreduction of NAu-2 (, e.g., 385 stayed at $3438 \mathrm{~cm}^{-1}$, Fig. $8 \mathrm{~F}$ ). The $v \mathrm{Si}-\mathrm{O}$ stretching region, representing tetrahedral layers, 386 is present from $1200 \mathrm{~cm}^{-1}$ to $950 \mathrm{~cm}^{-1}$ and produces a very intense peak due to its 387 structural dominance (Fialips et al., 2002; Gates, 2005). The position of the Si-O388 stretching band shifted from $1042 \mathrm{~cm}^{-1}$ to $1032 \mathrm{~cm}^{-1}$ upon bioreduction of ALA-NAu-2 389 (Fig. 8D). This shift to a lower frequency is consistent with previous studies of bacterially 390 reduced smectites (Lee et al., 2006). The final region of importance in IR spectra is the 
$\delta \mathrm{M}-\mathrm{OH}$ deformation bands $(\mathrm{M}=\mathrm{Mg}, \mathrm{Al}$ or $\mathrm{Fe})$ that ranges from $700 \mathrm{~cm}^{-1}$ to $950 \mathrm{~cm}^{-1}$. These bands are characteristics of the vibrations of the octahedral cations. The principal

$\mathrm{OH}, \mathrm{FeFe}-\mathrm{OH}$, and AlFe-OH, respectively (Fialips et al., 2002; Gates, 2005). The

396 bioreduction of structural Fe(III) in ALA-NAu-2 resulted in decreased intensities of the

$397785 \mathrm{~cm}^{-1}, 822 \mathrm{~cm}^{-1}$ and $875 \mathrm{~cm}^{-1}$ bands, and loss of the $848 \mathrm{~cm}^{-1}$ band (Fig. $8 \mathrm{E}$ ), similar to 398 those in bioreduced NAu-2 (Fig. 8H).

\subsection{Chemical reduction of Fe(III) in NAu-2 and ALA-NAu-2 by dithionite}

The rates and maximal extents of chemical reduction of structural $\mathrm{Fe}(\mathrm{III})$ in NAu-

2 and ALA-NAu-2 by the DCB procedure were much higher than those by the 403 methanogens (83\% and $91 \%$ for NAu-2, and ALA-NAu-2, respectively) with a 404 nearlycomplete release of ALA (only $\sim 0.38 \%$ remaining after Fe(III) reduction). Indeed, 405 when ALA release was plotted against the extent of Fe(III) reduction for both biological 406 and chemical reduction, a positive correlation resulted (Fig. 9).

Chemical reduction by DCB resulted in a decrease of $\mathrm{d}(001)$ spacing from 16.65 $408 \AA$ to $12.65 \AA$ for both NAu-2 and ALA-NAu-2 (Fig. 5C). High aqueous Si and Fe 409 concentrations in chemically reduced ALA-NAu-2 and NAu-2 (Fig. 3) suggested 410 reductive dissolution of these minerals. Under SEM, there were abundant dissolution pits 411 in ALA-NAu-2 forming a three-dimensional net-like texture (Fig. 6H), and these pits 412 displayed various sizes that were different from those cell-sized pits typically formed 413 after bioreduction of NAu-2 (Liu et al., 2011a; Zhang et al., 2012). DCB-reduced ALA- 
414 NAu-2 exhibited a similar composition to that of the rose-like bioreduced ALA-NAu-2

415 (i.e., absence of $\mathrm{Fe}$ and $\mathrm{C}$ contents) but without $\mathrm{K}$ (Fig. 6K).

416 FTIR data revealed that DCB reduction resulted in broad and low intensity ALA417 specific peaks $\left(1630 \mathrm{~cm}^{-1}, 2847 \mathrm{~cm}^{-1}\right.$, and $\left.2918 \mathrm{~cm}^{-1}\right)$ relative to those in unreduced 418 ALA-NAu-2, likely due to release of ALA from the NAu-2 interlayer (Fig. 8A \& B). The 419 overall position of the OH-stretching band shifted from $3426 \mathrm{~cm}^{-1}$ to $3451 \mathrm{~cm}^{-1}$ after 420 DCB reduction of Fe(III) in ALA-NAu-2 (Fig. 8C), but this peak did not shift after DCB 421 reduction of NAu-2 (Fig. 8F). The position of the Si-O-stretching band (Fig. 8D) shifted 422 from $1042 \mathrm{~cm}^{-1}$ to $1024 \mathrm{~cm}^{-1}$ after DCB reduction of ALA-NAu-2, and from $1032 \mathrm{~cm}^{-1}$ to $4231024 \mathrm{~cm}^{-1}$ after DCB reduction of NAu-2 (Fig. 8G). All peaks related to the $\mathrm{M}_{2}-\mathrm{OH}$ 424 deformation $\left(785 \mathrm{~cm}^{-1}, 822 \mathrm{~cm}^{-1}, 848 \mathrm{~cm}^{-1}\right.$, and $875 \mathrm{~cm}^{-1}$, assigned to FeMg-OH, FeFe$425 \mathrm{OH}, \mathrm{FeFe}-\mathrm{OH}$, and AlFe-OH, respectively) in ALA-NAu-2 and NAu-2 became broader 426 with lower intensities after DCB reduction (Fig. 8E\&H). In comparison with bioreduction 427 of $\mathrm{Fe}(\mathrm{III})$ in ALA-NAu-2 and NAu-2, chemical reduction by DCB resulted in much 428 lower intensities of all major bands (Fig. 8).

429 4. DISCUSSION

$430 \quad 4.1$ Effects of ALA intercalation on bioreduction and methanogenesis This research demonstrated that two methanogen strains could reduce structural $432 \mathrm{Fe}(\mathrm{III})$ in ALA-intercalated nontronite, but with lower bioreduction extents, rates, and 433 methane production relative to nontronite without ALA intercalation. These differences 434 could be explained by changes of NAu-2 properties as a result of ALA intercalation. ALA 435 is an amino acid analog that carries a carboxyl and an amino functional group, which 
436 should be zwitterionic (Lilley, 1985). Protonated ALA may enter the NAu-2 interlayer via 437 two mechanisms (Benincasa et al., 2000). First, protonated ALA can substitute for water 438 molecules in the nontronite interlayer such that NAu-2 becomes hydrophobic (Chou et al., 439 2005; Goebel et al., 2004; Jandl et al., 2004). This change from the hydrophilic to 440 hydrophobic nature makes the interlayer region unfavorable sites for water dispersion 441 (Chou et al., 2005). This water expulsion out of the interlayer and replacement by ALA 442 can hinder Fe(III) reduction, since the smectite interlayer region is important for electron 443 transfer process. Our previous results (Bishop et al., 2011; Liu et al., 2012; Zhang et al., 444 2012) demonstrated that the interlayer region of clay minerals is involved in the electron 445 transfer process, based on the observations that expandable smectites usually exhibit 446 higher extents and rates of Fe(III) bioreduction by various bacteria than non-expandable 447 illite (otherwise, isostructural with smectite). Second, the protonated ALA molecule may 448 replace the exchangeable cations, such as $\mathrm{Ca}^{2+}, \mathrm{Na}^{+}, \mathrm{K}^{+}$, on both the external surfaces and 449 the interlayer positions of NAu-2 (Alexander, 1999), which would form a coating of 450 organic matter on clay surfaces. This coating can block the sorption sites of clay minerals 451 (Onken and Traina, 1997; Shen and Jaffe, 2000; Charles et al., 2006). If the electron 452 transfer is perpendicular to the (001) layers (Dong et al., 2009), the intercalated ALA in 453 the interlayer region may block this electron transfer chain and result in lower extent and 454 rate of $\mathrm{Fe}(\mathrm{III})$ bioreduction, whereas surface-adsorbed ALA may have little or no effect. 455 If the electron transfer from methanol (M. mazei) and $\mathrm{H}_{2}$ (M. thermautotrophicus) to the 456 octahedral Fe(III) of the nontronite structure is parallel to (001) layers (Dong et al., 2009; 
457 Stucki et al., 2011), the sorbed ALA on NAu-2 external surfaces can hinder the electron 458 transfer and subsequently result in lower extent and rate of Fe(III) bioreduction. In this 459 case, the intercalated ALA would have little effect on this electron transfer mechanism. 460 Therefore, the relative role of parallel vs. perpendicular electron transfer in $\mathrm{Fe}(\mathrm{III})$ 461 bioreduction in iron-bearing clay minerals would determine the importance of surface462 adsorbed vs. intercalated-ALA in adversely affecting Fe(III) bioreduction.

463 When AQDS was supplied as an electron shuttle, the ALA blocking effect was 464 apparently alleviated for the $M$. mazei treatments because an equal amount of 465 bioreduction was achieved between NAu-2 and ALA-NAu-2 (Fig. 2). The likely reason 466 was that AQDS could easily enter the interlayer region and facilitate the electron transfer 467 from cells to the octahedral Fe(III) in ALA-NAu-2. This observation is consistent with 468 previous studies in showing that AQDS can significantly enhance the extent of Fe(III) 469 reduction in nontronite by mesophilic methanogens (Liu et al., 2011a; Zhang et al., 2012). 470 In experiments with $M$. thermautotrophicus (at $65^{\circ} \mathrm{C}$ ), however, AQDS did not 471 alleviate the ALA blocking effect, and AQDS had a minimal effect on the final extent of 472 bioreduction for both NAu-2 and ALA-NAu-2 (Fig. 2). A previous study (Zhang et al., 473 2013) also showed that AQDS did not enhance bioreduction of structural Fe(III) in NAu4742 by this thermophilic methanogen, likely because this strain might be able to produce its 475 own electron shuttle. In this case, the ALA blocking effect may have been from adsorbed 476 ALA only (on external surfaces of NAu-2). The melting temperature of ALA is about 477 $80^{\circ} \mathrm{C}$, so in the $M$. thermautotrophicus system $\left(65^{\circ} \mathrm{C}\right)$, some protonated ALA may have 
been partially melted, moved out of the nontronite interlayer and re-adsorbed onto the negatively charged cell and clay surfaces. Such sorption of ALA on cell surfaces would hinder microbial activity and might be partially responsible for observed lower extents of $\mathrm{Fe}(\mathrm{III})$ bioreduction (Fig. 2C) relative to those achieved by the mesophilic methanogen (Fig. 2A).

The observed inhibition of methanogenesis in the $M$. thermautotrophicus experimental system further supported this explanation. There were two stages of Fe(III) bioreduction in NAu-2 by M. thermautotrophicus, (Fig. 2D). According to our previous research (Zhang et al., 2013), the first phase of bioreduction may have been responsible for decreasing the reduction potential of the system so that methanogenesis could begin, which would provide more energy to support cell growth. High cell growth in turn promoted Fe(III) bioreduction at the second stage (Zhang et al., 2013). In contrast, such two-stage bioreduction was not observed in ALA-NAu-2 with the same thermophilic methanogen (Fig. 2C), and its Fe(III) bioreduction extent only reached $13.5-15.4 \%$, which was similar to the extent of Fe(III) bioreduction (15.6\%) when methanogensis was fully inhibited by $10 \mathrm{mM}$ 2-bromoethane sulfonate (Zhang et al., 2013). These data therefore suggest that ALA may have coated cell surfaces and decreased microbial activity. Methanogenesis is a membrane-bound electron transfer system (Deppenmeier, 2004). Therefore, a cell surface coating of ALA may have inactivated $M$. thermautotrophicus cells, inhibited methanogenesis (Fig. 7B), and lowered bioreduction (Fig. 2C). 
500 different from that by $M$. thermautotrophicus. Methanogenesis did not begin until

501 bioreduction ceased due to the diversion of electrons from $\mathrm{CO}_{2}$ to $\mathrm{Fe}$ (III) during this

502 stage (Liu et al., 2011a; Zhang et al., 2012). In our results, methane production in the

503 ALA-NAu-2 treatment began later than in the NAu-2 treatment, likely because of the

504 slower bioreduction rate in the ALA-NAu-2 treatment, but both ALA-NAu-2 and NAu-2

505 ultimately produced a similar amount of methane by the end of the experiments (Fig. 7A).

506 One likely reason was that at $37^{\circ} \mathrm{C}$ (the optimal growth temperature for M. mazei),

507 protonated ALA should have resided within the NAu-2 interlayer and would not be

508 available for sorption onto cell surfaces. So cell inactivation was not likely in this case

509 and the ultimate extent of methanogenesis was similar between ALA-NAu-2 and NAu-2

510 (Fig. 7A).

$512 \quad 4.2 \mathrm{ALA}$ release by $\mathrm{Fe}(\mathrm{III})$ reduction

513 Significant amounts of organic matter in sediments are usually associated with

514 mineral matrix, especially clay minerals, and can be physically protected against

515 biological oxidation (Baldock and Skjemstad, 2000). Although still subject to much

516 debate, sorption of organic matter to mineral surface is the most likely mechanism for the

517 observed physical protection of organic matter against oxidation in experimental

518 investigations (Mayer et al., 1985; Keil et al., 1994; Mayer, 1994). Recently, Lalonde et

519 al. (2012) developed a dithionite-based approach to reductively dissolve $\mathrm{Fe}$ in a wide 
520 range of sediment samples (iron oxides), and concluded that a certain amount of organic 521 matter in sediments was directly associated with and can be protected by iron oxides. Our 522 current result expanded that study by showing that the release of intercalated organic 523 matter was related to Fe reduction extent in clay minerals. In the present study, chemical 524 reduction by DCB resulted in nearly complete release of ALA from NAu-2 because it 525 reduced $80-90 \%$ of the structural Fe(III), whereas smaller biological reduction (13.5occurred to the NAu-2 structure.

The positive correlation between the amount of ALA release and the extent of Fe(III) reduction (Fig. 9) could be explained by reduction-related structural alterations 530 (Lee et al., 2006) and reductive dissolution of ALA-NAu-2. In chemically reduced ALA531 NAu-2, high extents of reductive dissolution were observed, as evidenced by extensive 532 dissolution pits (Fig. 6H), the lack of Fe and $\mathrm{C}$ in these dissolution pits (Fig. 6K), and high aqueous concentrations of $\mathrm{Si}$ and $\mathrm{Fe}$ (Fig. 3). In contrast, the extent of dissolution 534 was much less in bioreduced samples, as evidenced by lack of dissolution pits (instead rose-like textures observed, Fig. 6C), and lower aqueous Si and Fe concentrations (Fig. 3).

536 All these observations were consistent with previous results suggesting that reductive dissolution could be extensive when the extent of $\mathrm{Fe}(\mathrm{III})$ reduction was $>30 \%$, but 538 insignificant when the extent of reduction was <30\% (Jaisi et al., 2007; Dong et al., 2009). 539 Although ALA was largely preserved within the bioreduced nontronite interlayers, its Fe 540 and $\mathrm{C}$ contents were depleted relative to $\mathrm{Si}$ (Fig. 6F), suggesting partial dissolution. 
541 Therefore, intercalated organic matter release may be associated with reductive 542 dissolution of structural Fe(III) in ALA-NAu-2, but future work is needed to reveal the 543 causal relationship between organic matter release and $\mathrm{Fe}(\mathrm{III})$ reduction.

\subsection{Clay mineral transformation by methanogens in the presence of ALA} support their growth (Lovley et al., 1996; Lovley 2000, 2004; Stucki, 2006). As a result, solid minerals undergo structural and chemical changes (Dong, 2012). In our earlier

549 research, an extensive amount of vivianite was formed as a result of bioreduction of 550 structural Fe(III) in NAu-2 by M. mazei, along with observations of many dissolution pits, 551 high-charge smectite, and silica aggregates (Zhang et al., 2012). Such formation of new 552 minerals during bioreduction implied that structural changes of nontronite by M. mazei 553 may be irreversible. However, in the presence of ALA, dissolution pits, high-charge 554 smectite, and vivianite were not observed after bioreduction, suggesting that 555 bioreduction-induced mineralogical alterations may be small for ALA-intercalated 556 nontronite.

Previous research has shown that the type of organic matter may determine the 558 degree of mineralogical changes (Zhang et al., 2007a). When the intercalated organic 559 matter was an essential nutrient for microbes (such as amino acid), its presence would be 560 attractive to microbes and could result in a higher extent of bioreduction to promote 561 mineralogical change. However, if the organic matter intercalated into the nontronite 562 structure was toxic to cells (such as toluene), Fe(III) bioreduction would be inhibited and 563 no mineralogical changes were observed. In our study, ALA is neither toxic nor 
564 beneficial to the methanogens, so mineralogical alterations of $\mathrm{NAu}-2$ were observed to be 565 small, as expected.

\subsection{Environmental Implications}

Our experiments showed that the amount of organic matter released from

569 nontronite depended on the extent of reduction of structural Fe(III) in nontronite.

570 Although the bioreduction extents (13.5-28.1\%) were much lower than those by chemical

571 reduction, biological reduction is more relevant to natural environments because

572 chemical reductant such as sodium dithionite is not commonly present in nature.

573 Therefore, organic matter should be largely protected from microbial degradation if it is

574 within smectite clay minerals. Such organic matter-smectite association could explain the

575 positive correlation between the abundance of TOC and smectite in various sedimentary

576 rocks (Mayer et al., 1985; Mayer, 1994; Keil et al., 1994; Ransom et al., 1998; Arnarson

577 and Keil, 2001; Kennedy et al., 2002; Kennedy and Wagner, 2011). However, we note

578 that our experiments may not be entirely representative of natural sediments because

579 iron-rich smectite, i.e., nontronite, is not a common smectitic clay mineral. Nonetheless,

580 this study does offer a mechanistic understanding of organic matter release from smectite 581 clay minerals.

582 Certain expandable clay minerals are widely utilized for remediation of organic 583 contaminants by intercalating/sequestering them into the interlayers of montmorillonite in 584 order to isolate them from the environment (Mulligan et al., 2001; Walcarius and Mercier, 585 2010). The results of this study offer important insights into the role of microbial 586 activities on clay mineral transformation and subsequent organic matter release. If the 
587 clay mineral contains a certain amount of structural Fe(III) and natural metal-reducing 588 microbes can reduce Fe(III), the organic contaminants should be largely protected within 589 smectite structure. An improved understanding of iron biogeochemistry of clay minerals 590 will be valuable for designing remediation technologies for sequestering organic 591 contaminants.

\section{CONCLUSION}

During the reduction of structural Fe(III) in nontronite (NAu-2) either biologically by methanogens $M$. maize and $M$. thermautotrophicus or chemically by sodium dithionate, the intercalated ALA was partially released, and the extent of release was correlated with

597 the extent of $\mathrm{Fe}(\mathrm{III})$ reduction. Bioreduction exhibited lower $\mathrm{Fe}(\mathrm{III})$ reduction with 598 release of only $2 \%$ ALA, whereas chemical reduction showed much higher Fe(III) 599 reduction extent and release of nearly all the intercalated ALA. SEM observations and 600 aqueous chemistry data support the argument that reductive dissolution was a main 601 mechanism for ALA release from nontronite structure. Since biological reduction should 602 be more prevalent than chemical reduction in natural environment, the results of this 603 study suggest that organic matter should be largely preserved within the nontronite 604 structure. In addition, ALA intercalation into the nontronite interlayer exhibited a stronger 605 inhibition effect of methanogenesis than NAu-2 alone by $M$. thermautotrophicus, likely 606 due to a combination of multiple factors including reduction potential and physical 607 blocking of the electron transfer chain by ALA.

608 
610 This work was supported by grants from the National Basic Research Program of 611 China (No. 2011CB808800 and 2012CB822004), Natural Science Foundation of China 612 (41030211 \& 41072253), and the Subsurface Biogeochemical Research (SBR) Program, 613 Office of Science (BER), U.S. Department of Energy (DOE) (No. DESC0005333). We 614 thank Dr. Peng Yuan at the Institute of Geochemistry, Chinese Academy of Science for 615 help in ALA-nontronite synthesis. We are grateful to two anonymous reviewers whose 616 comments improved the quality of the manuscript. 


\section{REFERENCES}

Achtnich, C., Bak, F., Conrad, R., 1995. Competition for electron donors among nitrate reducers, ferric iron reducers, sulfate reducers, and methanogens in anoxic paddy soil. Biology and Fertility of Soils 19, 65-72.

Alexander, M., 1999. Biodegradation and bioremediation, 2nd edn. Academic Press, London.

Amonette, J.E., Templeton, J.C., 1998. Improvements to the quantitative assay of nonrefractory minerals for $\mathrm{Fe}(\mathrm{II})$ and total Fe using 1,10-phenanthroline. Clays Clay minerals 46, 51-62.

Arnarson, T.S. and Keil, R.G., 2001. Organic-mineral interactions in marine sediments studied using density fractionation and X-ray photoelectron spectroscopy. Organic Geochemistry, 32, 1401-1415.

Baldock, J.A. and Skjemstad, J.O., 2000. Role of the soil matrix and minerals in protecting natural organic materials against biological attack. Organic Geochemistry 31, 697-710.

Barth, A., 2000. The infrared absorption of amino acid side chains. Progress in Biophysics and Molecular Biology 74, 141-173.

Beckmann, B., Flögel, S., Hofmann, P., Wagner, T., 2005. Mid-Cretaceous African climate development and implications for the marine carbon cycle. Nature 437, 
Benincasa, E., Brigatti, M.F., Lugli, C., Medici, L., Poppi, L., 2000. Interaction between glycine and Na-, $\mathrm{Ca}$ and $\mathrm{Cu}$-rich smectites. Clay Minerals 35, 635-641.

Bennett, B., Adams, J.J., Gray, N.D., Sherry, A., Oldenburg, T.B.P., Huang, H., Larter, S.R., Head, I.M., 2013.The controls on the composition of biodegraded oils in the deep subsurface - Part 3. The impact of microorganism distribution on petroleum geochemical gradients in biodegraded petroleum reservoirs. Organic Geochemistry 56, 94-105.

Bishop, M.E., Dong, H., Kukkadapu, R.K., Edelmann, R.E., 2011. Bioreduction of Febearing clay minerals and their reactivity toward pertechnetate (Tc-99). Geochim. Cosmochim. Acta 75, 5229-5246.

Bond, D.R. and Lovley, D.R., 2002. Reduction of Fe(III) oxide by methanogens in the presence and absence of extracellular quinones. Environmental Microbiology 4, $115-124$.

Boone, R.D. and Mah, A.R., 1987. Effects of calcium, magnesium, pH, and extent of Growth on the morphology of Methanosarcina mazei S-6. Applied and environmental microbiology 53, 1699-1700.

Brigatti, M.F., Lugli, C., Montorsi, S., Poppi, L., 1999. Effects of exchange cations and layer-charge location on cysteine retention by smectites. Clays and Clay Minerals 
47, 664-671.

Charles, S., Teppen, B.J., Li, H., Laird, D.A., Boyd, S.A., 2006. Exchangeable cation hydration properties strongly influence soil sorption of nitroaromatic compounds. Soil Science Society of America Journal 70, 1470-1479.

Chou, C., Chiang, M., Lin, J., 2005. Unusual intercalation of cationic smectite clays with detergent-ranged carboxylic ions. Macromolecular Rapid Communications 26, 1841-1845.

Deppenmeier, U., 2004. The membrane-bound electron transport system of Methanosarcina Species. Journal of Bioenergetics and Biomembranes 36, 55-64.

Dong, H., Kukkadapu, R.K., Fredrickson, J.K., Zachara, J.M., Kennedy, D.W., Kostandarithes, H.M., 2003. Microbial reduction of structural Fe(III) in illite and goethite by a groundwater bacterium. Environmental Science \& Technology 37, 1268-1276.

Dong, H., Jaisi, D.P., Kim, J.W., Zhang, G., 2009. Microbe-clay mineral interactions. American Mineralogist 94, 1505-1519.

Dong, H., 2012. Clay-Microbe Interactions and Implications for Environmental Mitigation. Elements 8 113-118.

Galy, V., France-Lanord, C., Beyssac, O., Faure, P., Kudrass, H., Palhol, F., 2007. 
Efficient organic carbon burial in the Bengal fan sustained by the Himalayan erosional system. Nature 450, 407-410.

Fialips, C.I., Huo, D., Yan, L., Wu, J., Stucki, J.W., 2002. Infared study of reduced and reduced-reoxidized ferruginous smectite. Clays and Clay Minerals 50, 455-469.

Gates, W.P., 2005. Infrared spectroscopy and the chemistry of dioctahedral smectites. Pp. 125-168 in: The Application of Vibrational Spectroscopy to Clay Minerals and Layered Double Hydroxides (J.T. Kloprogge, editor). CMS Workshop Lectures, Vol. 13. The Clay Minerals Society, Aurora, CO.

Goebel, M.O., Bachmann, J., Woche, S.K., Fischer, W.R., Horton, R., 2004. Water potential and aggregate size effects on contact angle and surface energy. Soil Science Society of America Journal 68, 383-393.

Huguet, C.E.J., De Lange, G.J., Gustafsson, O., Middelburg, J.J., Sinninghe-Damsté, J.S., Schouten, S., 2008. Selective preservation of soil organic matter in oxidized marine sediments (Madeira Abyssal Plain). Geochimica et Cosmochimica Acta 72, 6061-6068.

Jaisi, D.P., Kukkadapu, R.K., Eberl, D.D., Dong, H., 2005. Control of Fe(III) site occupancy on the rate and extent of microbial reduction of $\mathrm{Fe}(\mathrm{III})$ in nontronite. Geochimica et Cosmochimica Acta 69, 5429-5440.

Jaisi, D.P., Dong, H., Liu, C., 2007. Influence of biogenic Fe(II) on the extent of 
microbial reduction of $\mathrm{Fe}(\mathrm{III})$ in clay mineral nontronite, illite, and chlorite. Geochimica et Cosmochimica Acta 71, 1145-1158.

Jaisi, D.P., Dong, H., and Morton, J.P. (2008a) Partitioning of Fe(II) in reduced nontronite (NAu-2) to reactive sites: Reactivity in terms of $\mathrm{Tc}(\mathrm{VII})$ reduction. Clays and Clay Minerals, 56, 175-189.

Jandl G., Leinweber P., Schulten H.-R., Eusterhues K., 2004. The concentrations of fatty acids in organo-mineral particle-size fractions of a Chernozem. European Journal of Soil Science 55, 459-469.

Jenkyns, H.C., 2003. Evidence for rapid climate change in the Mesozoic-Palaeogene greenhouse world. Philosophical Transactions of the Royal Society A 361, 18851916.

Keil, R.G., Montlucon, D.B., Prahl, F.G., Hedges, J.I., 1994. Sorptive preservation of labile organic material in marine sediments. Nature, 370 549-552.

Kenealy, W., Zeikus, J.G., 1981. Influence of corrinoid antagonists on methanogen metabolism. Journal of Bacteriology 146, 133-140.

Kennedy, M.J., Pevear, D.R., Hill, R.H., 2002. Mineral surface control of organic carbon in black shale. Science 295, 657-660.

Kennedy, M., Droser, M., Mayer, M.L., Pevear, D., Mrofka, D., 2006. Late Precambrian 
Oxygenation; Inception of the Clay Mineral Factory. Science 311, 1446-1449.

Kennedy, M.J., Wagner, T., 2011. Clay mineral continental amplifier for marine carbon sequestration in a greenhouse ocean. Proceedings of the National Academy of Sciences of the United States of America 108, 9776-9781.

Kostka, J.E., Stucki, J.W., Nealson, K.H., Wu, J., 1996. Reduction of structural Fe(III) in smectite by a pure culture of Shewanella putrefaciens strain MR-1. Clays \& Clay Minerals 44, 522-529.

Lahlou, M., Harms, H., Springael, D., Ortega-Calvo, J.J., 2000. Influence of soil components on the transport of polycyclic aromatic hydrocarbon-degrading bacteria through saturated porous media. Environmental Science \& Technology 34, 3649-3656.

Lalonde, K., Mucci, A., Ouellet, A., Gelinas, Y., 2012. Preservation of organic matter in sediments by iron. Nature 483, 198-200.

Lee, K., Kostka, J.E., Stucki, J.W., 2006. Comparisons of structural iron reduction in smectites by bacteria and dithionite: An infrared spectroscopic study. Clays and Clay Minerals 54, 197-210.

Li, Y.L., Zhang, C.L., Yang, J., Deng, B., and Vali, H. (2004) Dissolution of nontronite NAu-2 by a sulfate-reducing bacterium. Geochimica et Cosmochimica Acta, 68, $3251-3260$. 
Lilley, T.H., 1985. Physical properties of amino acid solutions. Pp. 591 - 625 in: Chemistry and Biochemistry of the Amino Acids (G.C. Barret, editor). Oxford Polytechnic, Oxford, UK.

Liu, D., Dong, H., Bishop, E.M., Wang, H., Agrawal, A., Tritschler, S., Eberl, D.D., Xie S., 2011a. Reduction of structural Fe(III) in nontronite by methanogen Methanosarcina barkeri. Geochimica et Cosmochimica Acta 75, 1057-1071.

Liu, D., Dong, H., Bishop, E.M., Zhang, J., Wang, H., Xie, S., Wang, S., Huang, L., Eberl D.D., 2012. Microbial reduction of structural iron in interstratified illite-smectite minerals by a sulfate-reducing bacterium. Geobiology, 10, 150-162.

Liu, M., Pu, M., Ma H., Hu, Y., Liu, X., Pang X., 2011b. The effect of organic modifier12-aminolauric acid on morphology and thermal properties of polylactide nanocomposites. Polymer Composites, 10, 1002-1008.

Lovley, D.R. and Philips, E.J.P., 1988. Novel mode of microbial energy metabolism: Organic carbon oxidation coupled to dissimilatory reduction of iron or manganese. Applied and Environmental Microbiology 54, 1472-1480.

Lovley, D.R., Coates, J.D., Blunt-Harris, E.L., Phillips, E.J.P., Woodward, J.C., 1996. Humic substances as electron acceptors for microbial respiration. Nature 382, 445-448.

Lovley, D.R., Fraga, J.L., Blunt-Harris, E.L., Hayes, L.A., Phillips, E.J.P., Coates, J.D., 
1998. Humic substances as a mediator for microbially catalyzed metal reduction. Acta Hydrochimica et Hydrobiologica 26, 152-157.

Lovley, D.R., 2000. $\mathrm{Fe}^{3+}$ and $\mathrm{Mn}(\mathrm{IV})$ reduction. In D.R. Lovley, Ed., Environmental microbe-metal interactions, p. 3.30. ASM Press, Washington, D.C.

Lutzow, M.V., Kogel-Knabner, I., Ekschmitt, K., Matzner, E., Guggenberger, G., Marschner, B., Flessa, H., 2006. Stabilization of organic matter in temperate soils: mechanisms and their relevance under different soil conditions - a review. European Journal of Soil Science 57, 426-445.

Mayer, L.M., Rahaim, P., Guerin, P., Macko, S.A., Watling, L., Anderson, F.E., 1985. Biological and granulometric controls on organic matter of an intertidal mudflat. Estuarine, Coastal and Shelf Science 20, 491-503.

Mayer, L.M., 1994. Surface area control of organic carbon accumulation in continental shelf sediments. Geochimica et Cosmochimica Acta 58, 1271-1284.

Mayer, L.M. and Xing, B., 2001. Organic carbon-surface area-clay relationships in acid soils. Soil Science Society of America Journal 65, 250-258.

Moore, D.M. and Reynolds, Jr., R.C., 1997. X-ray Diffraction and the identification and Analysis of Clay Minerals (Vols. Ch. 1, 2, \& 3). Oxford University Press, New York. 
Morrison, K.D., Bristow, T.F., Kennedy, M.J., 2013. The reduction of structural iron in ferruginous smectite via the amio acid cysteine: Implications for an electron shuttling compound. Geochimica et Cosmochimica Acta 106, 152-163.

Mulligan, C.N., Yong, R.N., Gibbs, B.F., 2001. Surfactant-enhanced remediation of contaminated soil: a review. Engineering Geology 60, 371-380.

Myers, C.R. and Nealson, K.H., 1988. Bacterial manganese reduction and growth with manganese oxide as the sole electron acceptor. Science 240, 1319-1321.

Negri, A, Ferretti, A, Wagner, T, Meyers, P.A., 2009. Phanerozoic organic-carbon-rich marine sediments: Overview and future research challenges. Palaeogeography, Palaeoclimatology, Palaeoecology 273, 218-227.

Onken, B.M. and Traina, S.J., 1997. The sorption of pyrene and anthracene to humic acid-mineral complexes: effect of fractional organic carbon content. Journal of Environmental Quality 26, 126-132

Rabalais, N.N., Turner, R.E., Diaz, R.J., Jusrtic, D., 2009. Global change and eutrophication of coastal waters. ICES Journal of Marine Science 66, 1528-1537.

Ransom, B., Dongseon, K., Kastner, M., Wainwright, S., 1998. Organic matter preservation on continental slopes: Importance of mineralogy and surface area. Geochimica et Cosmachimica Acta 62, 1329-1345. 
Rozenson, I. and Heller-Kallai, L., 1976. Reduction and oxidation of $\mathrm{Fe}^{3+}$ in dioctahedral smectites-1: reduction with hydrazine and dithionite. Clays and Clay Minerals 24, 271-282.

Schwarzenbach, R.P., Gschwend, P.M., Imboden, D.M., 1995. Environmental Organic Chemistry, Illustrative Examples, Problems, and Case Studies. John Wiley and Sons, Inc., New York.

Shen, L. and Jaffe, R., 2000. Interactions between dissolved petroleum hydrocarbons and pure andhumic acid-coated mineral surfaces in artificial seawater. Marine Environmental Research 49, 217-231

Stucki, J.W., Golden, D.C., Roth, C.B., 1984. The effect of reduction and reoxidation on the surface charge and dissolution of dioctahedral smectites. Clays Clay Minerals $32,350-356$.

Stucki, J.W., 2006. Properties and behaviour of iron in clay minerals. In: Bergaya, F., Theng, B.K.G., Lagaly, G. (Eds.), Handbook of Clay Science. Elsevier, Amsterdam, pp. 429-482.

Stucki, J.W. and Kostka, J.E., 2006. Microbial reduction of iron in smectite. Comptes Rendus Geoscience 338, 468-475.

Stucki, W.J., 2011. A review of the effects of iron redox cycles on smectite properties. Comptes Rendus Geoscience 343, 199-209. 
Van Bodegom, P.M. and Stams, A.J.M., 1999. Influence of alternative electron acceptors on methanogenesis in rice paddy soils. Chemosphere 39, 167-182.

Van Bodegom, P.M., Scholten, J.C.M., Stams, A.J.M., 2004. Direct inhibition of methanogenesis by ferric iron. FEMS Microbiology Ecology 49, 261-268.

Walcarius, A. and Mercier, L., 2010. Mesoporous organosilica adsorbents: nanoengineered materials for removal of organic and inorganic pollutants. Journal of Materials Chemistry 20, 4478-4511.

Weber, A.K., Achenbach, A.L., Coates, D.J., 2006. Microorganisms pumping iron: anaerobic microbial iron oxidation and reduction. Nature Reviews Microbiology 4, $752-764$

Zehnder, A.J.B. and Wuhermann, K., 1977. Physiology of a Methanobacterium strain AZ. Archives of Microbiology 111, 199-205.

Zhang, G., Kim, J.W., Dong, H., Sommer, A.J., 2007a. Microbial effects in promoting the smectite to illite reaction: Role of organic matter intercalated in the interlayer. American Mineralogist 92, 1401-1410.

Zhang G., Dong H., Kim J.W., and Eberl D.D. 2007b. Microbial reduction of structural $\mathrm{Fe}^{3+}$ in nontronite by a thermophilic bacterium and its role in promting the smectite to illite reaction. American Mineralogist 92, 1411-1419. 
Zhang, J., Dong, H., Liu, D., Fischer, B.T., Wang, S., Huang, L., 2012. Microbial reduction of $\mathrm{Fe}(\mathrm{III})$ in illite-smectite minerals by methanogen Methanosarcina mazei. Chemical Geology 292-293, 35-44.

Zhang, J., Dong, H., Liu, D., Agrawal, A., 2013. Microbial Reduction of Fe(III) in Smectite Minerals by Thermophilic Methanogen Methanothermobacter Thermautotrophicus. Geochimica et Cosmochimica Acta 106, 203-215.

\section{FIGURE CAPTION}

Fig. 1. A) XRD patterns showing ALA intercalation into the NAu-2 interlayer. The 001 peak of NAu-2 moved from 12.18 to $16.65 \AA$ after intercalation. B) FTIR spectra for NAu-2, ALA, and ALA-NAu-2.

Fig. 2. Production of total Fe(II) in ALA-NAu-2 and NAu-2 by $M$. mazei and $M$. thermautotrophicus with time as measured by the 1,10-phenanthroline method. Initial cell concentration was $10^{8}$ cells $/ \mathrm{mL}$. Averages of two measurements from duplicate experimental tubes were reported. The error bars represent the higher and lower values. Control A did not have any cells. (A). Reduction of structural Fe(III) in ALA-NAu-2 by M. mazei; (B). Reduction of structural Fe(III) in NAu-2 by M. mazei; (C). Reduction of 
structural Fe(III) in ALA-NAu-2 by M. thermautotrophicus; (D). Reduction of structural Fe(III) in NAu-2 by M. thermautotrophicus.

Fig. 3 Aqueous concentrations of $\mathrm{Si}$ and $\mathrm{Fe}$ as a function of reduction extent for NAu-2 (A) and ALA-NAu-2 (B) suspensions in the presence of AQDS. In each plot, the first five data points are for bioreduced samples and the last data point is for chemically reduced NAu-2 or ALA-NAu-2.

Fig. 4. Time-course decrease of TOC content (wt \%) in ALA-NAu-2 and NAu-2 samples over the course of Fe(III) bioreduction. Control A did not have any cells. The error bars represent the higher and lower values from duplicated measurements. (A). with M. mazei; (B). with M. thermautotrophicus.

Fig. 5. XRD patterns showing change of the d(001) spacing for ALA-NAu-2 before and after bioreduction by M. mazei (A) and M. thermautotrophicus (B), respectively. The $\mathrm{d}(001)$ peak intensity in all treatments decreased after bioreduction. C) XRD patterns of the DCB-reduced ALA-NAu-2 showing the same pattern as that for the DCB-reduced $\mathrm{NAu}-2$.

Fig. 6. Secondary electron images showing NAu-2 and ALA-NAu-2 after 100 days of 
bioreduction. A) abiotic control of NAu-2; B) abiotic control of ALA-NAu-2; C) roselike texture in bioreduced ALA-NAu-2; D) EDS spectrum of unreduced NAu-2 in the abiotic control (from point A1 in Fig. 5A); E) EDS spectrum of unreduced ALA-NAu-2 in the abiotic control (from point A2 in Fig. 5B); F) EDS spectrum of rose-like textured particles in bioreduced ALA-NAu-2 (from point A3 in Fig. 5C); G) plate-shaped clay particles and silica aggregates in bioreduced ALA-NAu-2; H) net-shaped ALA-NAu-2 after DCB reduction; I) EDS spectrum of plate-shaped clay particles in bioreduced ALANAu-2 (from point A4 in Fig. 5G); J) EDS spectrum of silica aggregates after bioreduction of NAu-2 (from point A5 in Fig. 5G); K) EDS spectrum of net-shaped ALANAu-2 after DCB reduction (from point A6 in Fig. 5H). In all EDS spectra, the Au peak was from sample coating.

Fig. 7. Time-course methane production by M. mazei (A) and M. thermautotrophicus (B) in all experimental treatments. The error bars represent the higher and lower values from duplicated measurements. Control B did not have any clay minerals. Control C was for the NAu-2 treatments (with ALA intercalation).

Fig. 8. FTIR spectra for ALA-NAu-2 and reduced ALA-NAu-2 (A-E) and for NAu-2 and reduced NAu-2 (F-H). A) The $v \mathrm{CH} 2$ stretching bands in ALA-NAu-2, bioreduced ALA$\mathrm{NAu}-2$, and DCB reduced ALA-NAu-2. B) $\delta \mathrm{NH}^{+}$deformation and $v_{\mathrm{as}} \mathrm{COO}^{-}$ asymmetrical stretching bands in ALA-NAu-2, bioreduced ALA-NAu-2, and DCB 
reduced ALA-NAu-2. C) OH-stretching bands in ALA-NAu-2, bioreduced ALA-NAu-2, and DCB reduced ALA-NAu-2. D) Si-O stretching bands in ALA-NAu-2, bioreduced ALA-NAu-2, and DCB reduced ALA-NAu-2. E) $\mathrm{M}_{2}-\mathrm{OH}$ bending bands in ALA-NAu-2, bioreduced ALA-NAu-2, and DCB reduced ALA-NAu-2. F) OH-stretching bands in NAu-2, bioreduced NAu-2, and DCB reduced NAu-2. G) Si-O stretching bands in NAu-2, bioreduced NAu-2, and DCB reduced NAu-2. $\mathrm{H}$ ) $\mathrm{M}_{2}-\mathrm{OH}$ bending bands in NAu-2, bioreduced NAu-2, and DCB reduced NAu-2.

Fig. 9. A positive correlation between TOC release and the extent of Fe(III) reduction. Those points with the reduction extent $<30 \%$ are for bioreduced ALA-NAu- 2 and the last few points (>80\% reduction extent) are for chemically reduced ALA-NAu-2. 

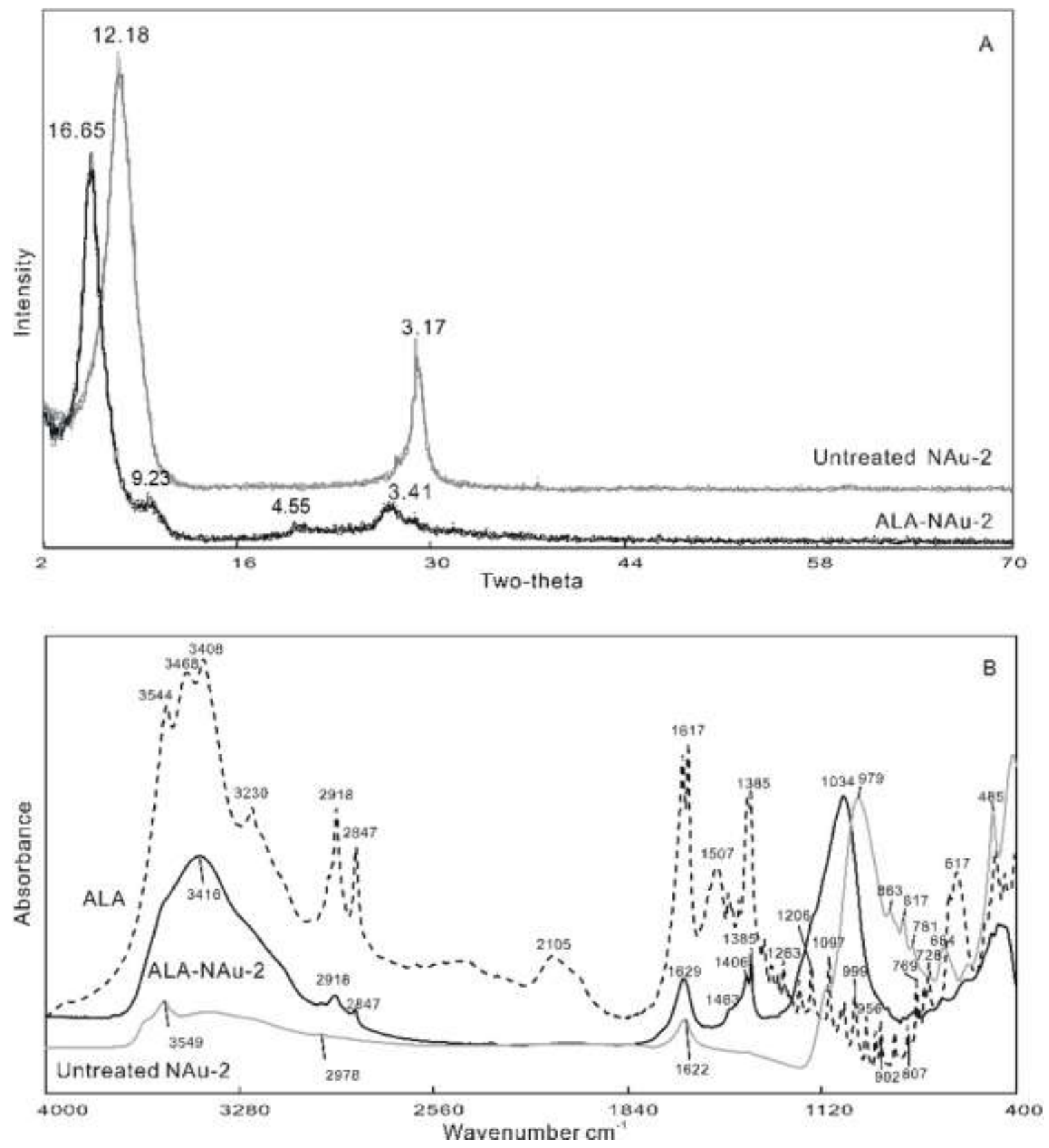

Fig. 1 

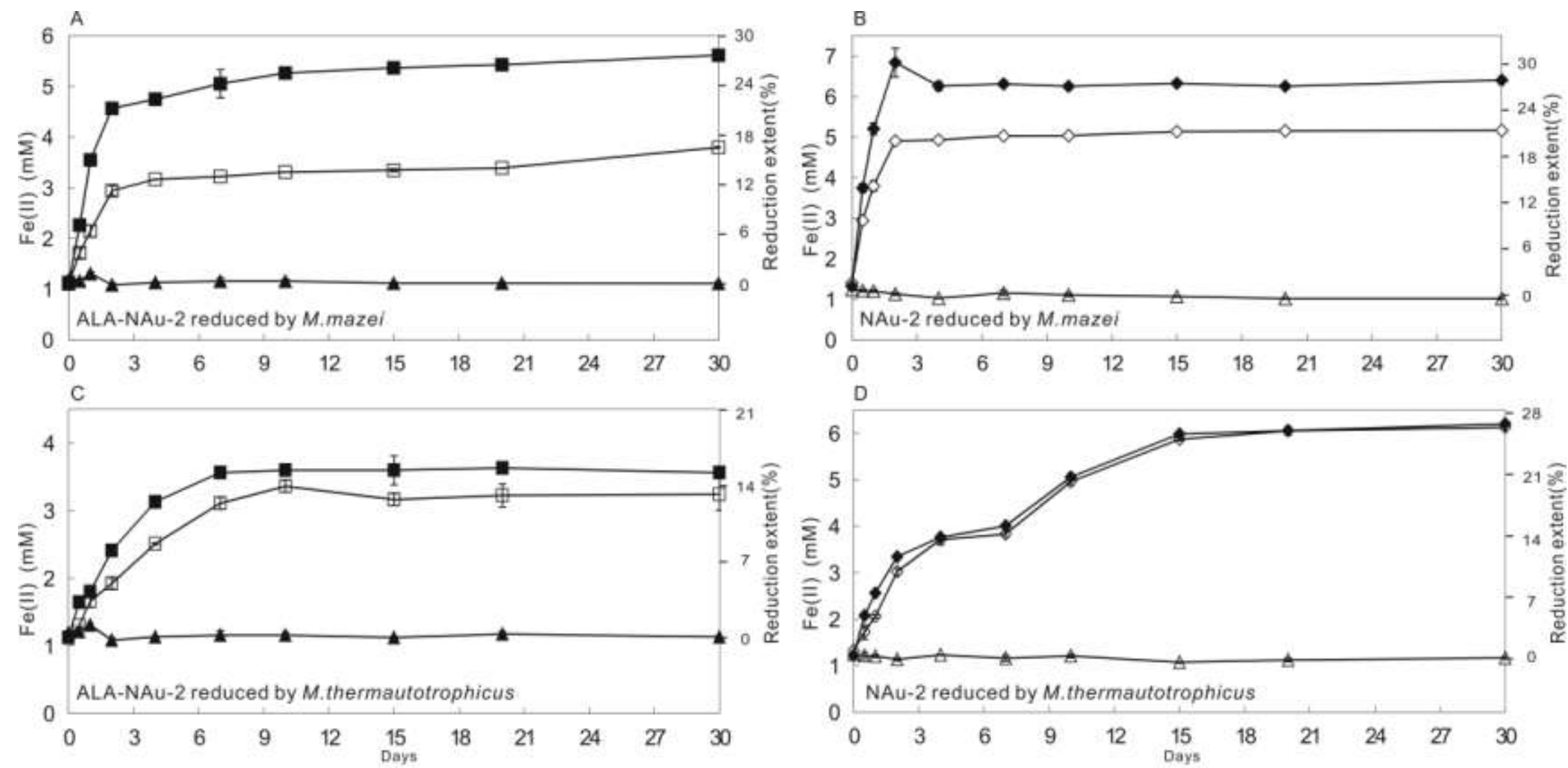

Control A Group

-Abiotic control with ALA-NAu-2

$\triangle$ - Abiotic control with NAU-2

- - Cell + AQDS with ALA-NAu-2 - Cell + AQDS with NAu-2

$\rightarrow-$ Cell with ALA-NAu-2 $\quad$-Cell with NAu-2

Fig. 2 


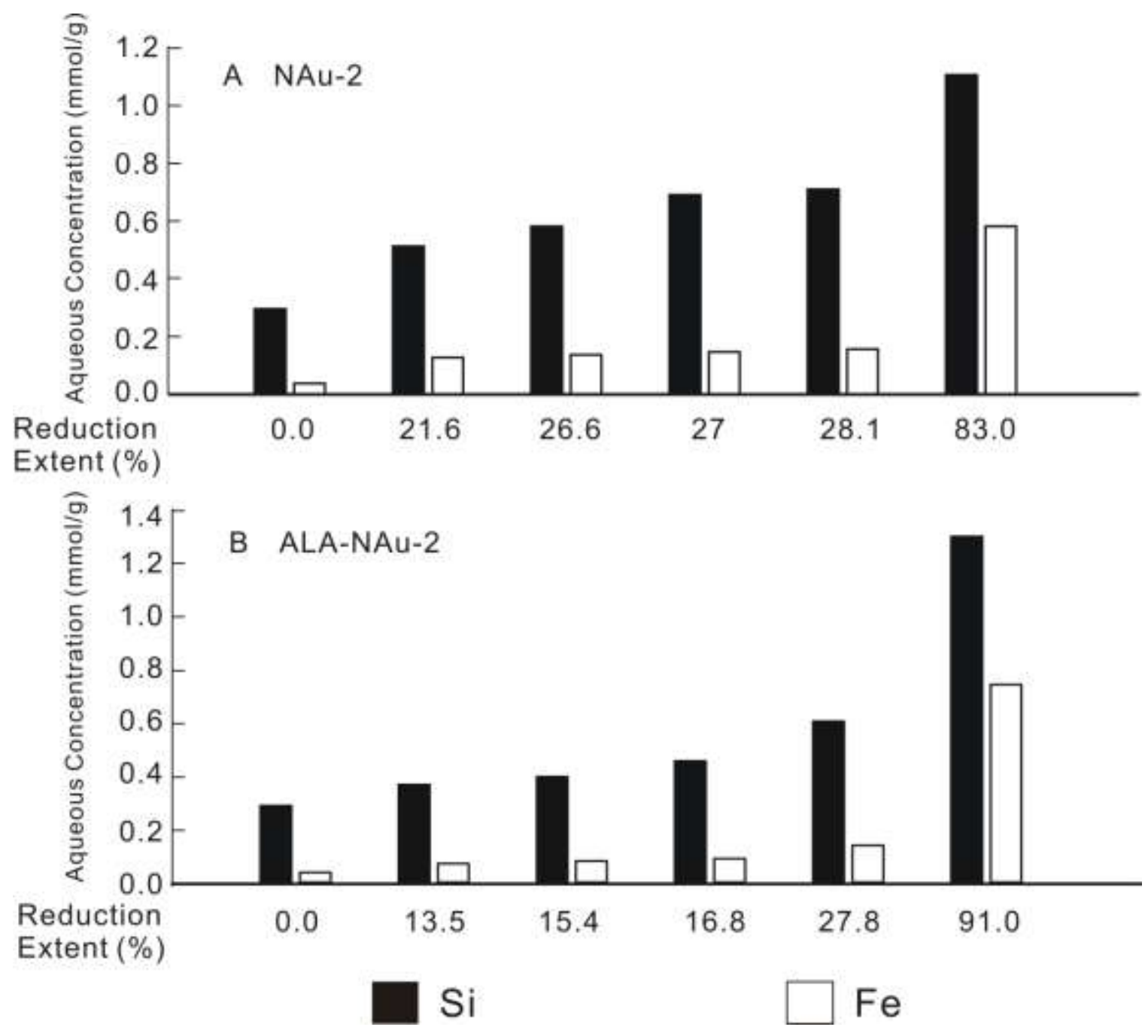

Fig. 3 

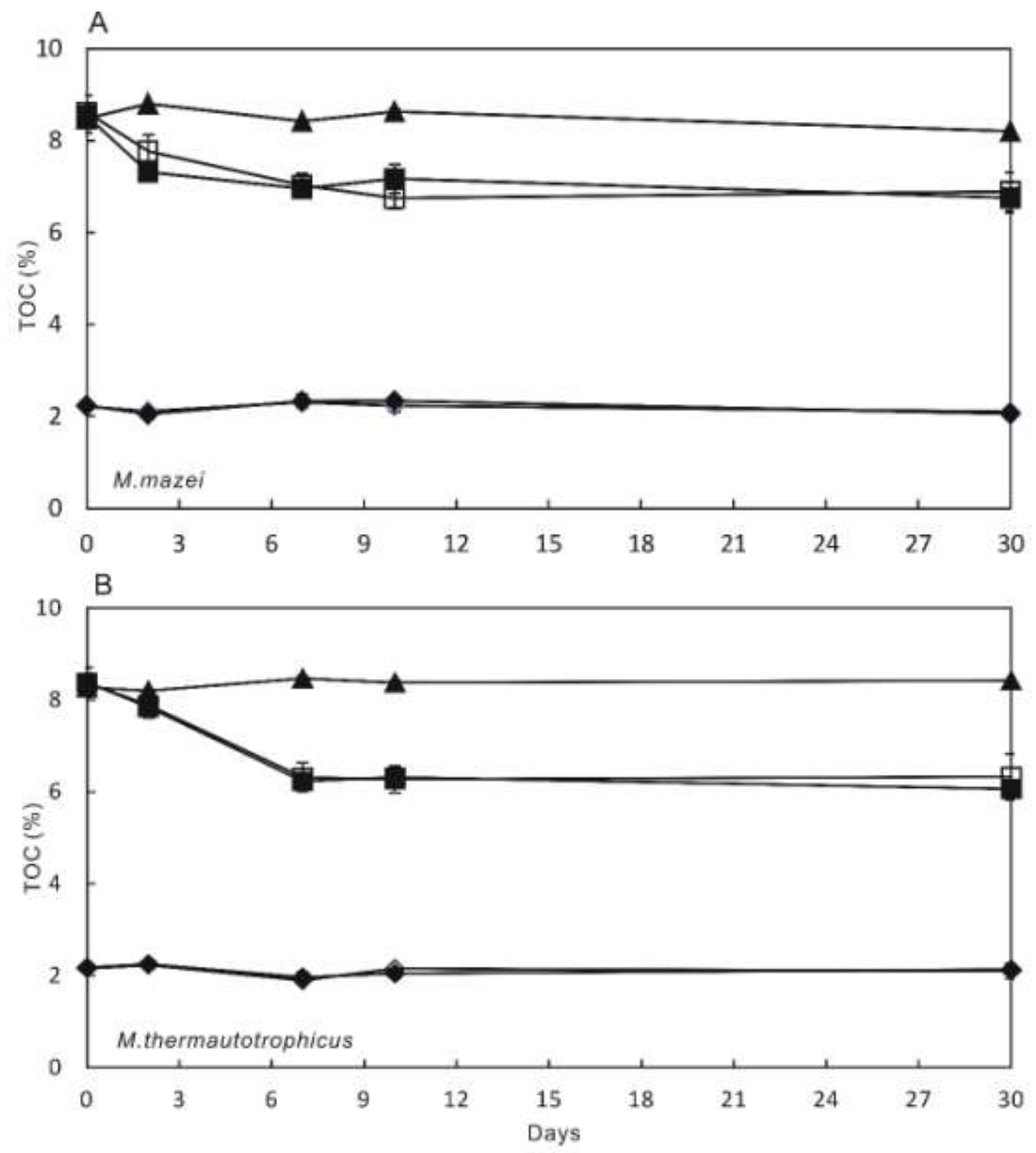

\begin{tabular}{c|c|c}
\multicolumn{1}{c|}{ Control A Group } & \multicolumn{1}{c}{ Experimental Group } & \multicolumn{1}{c}{ Control C Group } \\
- Ablotic control with ALA-NAu-2 & $\rightarrow$ Cell + AQDS with ALA-NAu-2 & $\rightarrow$ Cell + AQDS with NAu-2 \\
$\rightarrow-$ Cell with ALA-NAu-2 & - Cell with NAu-2
\end{tabular}

Fig. 4 

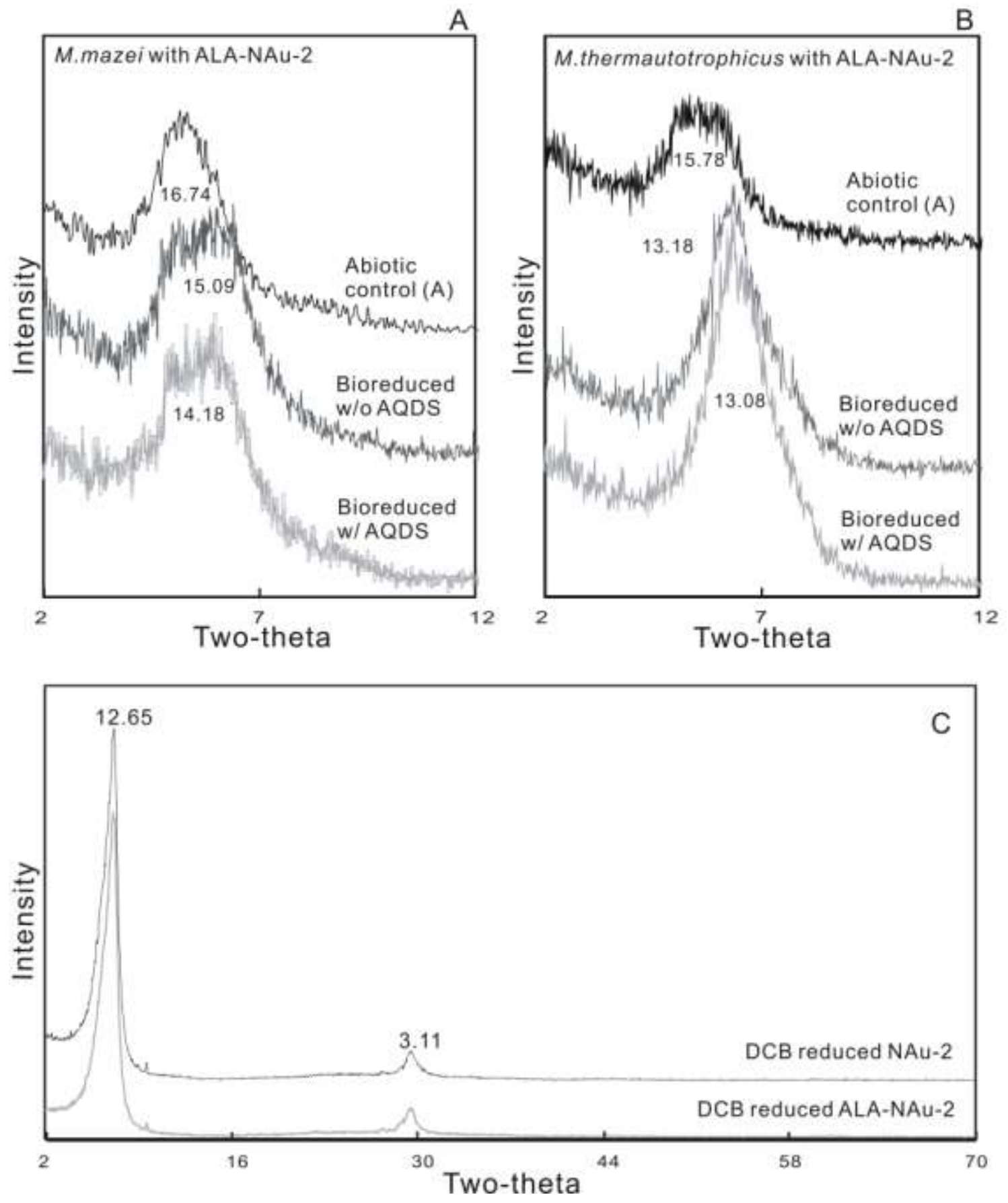

Fig. 5 

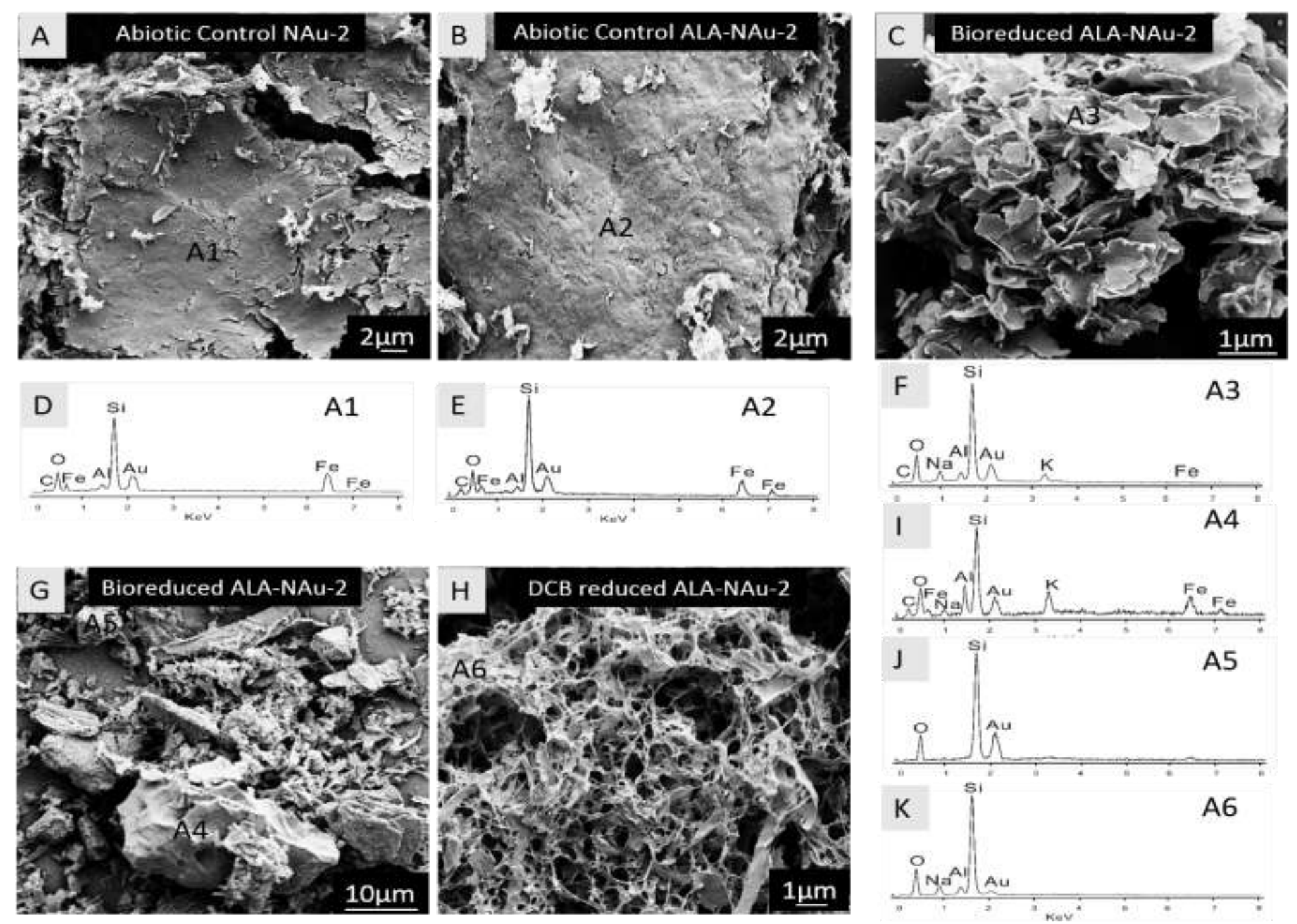

Fig. 6 

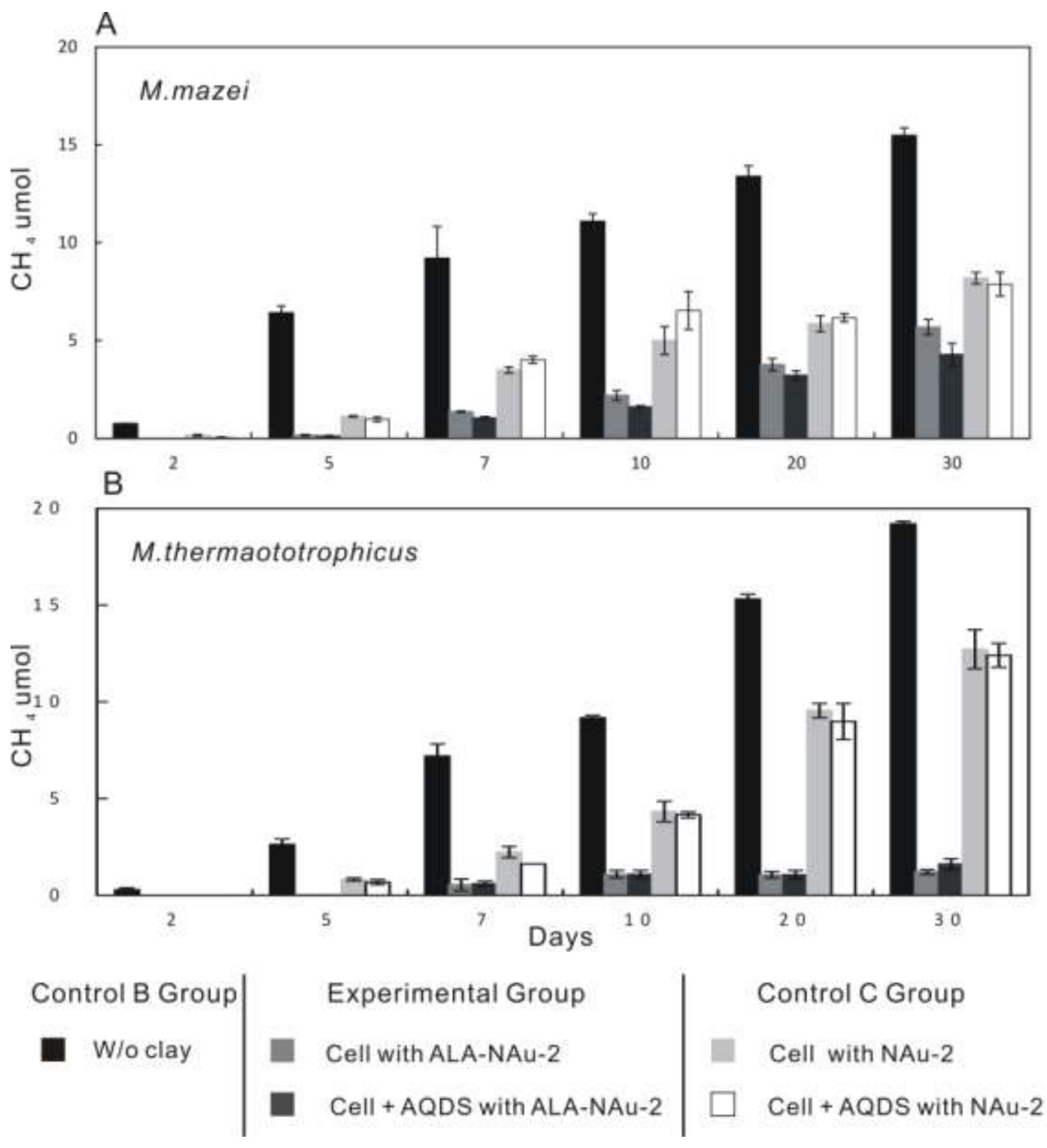

Fig. 7 


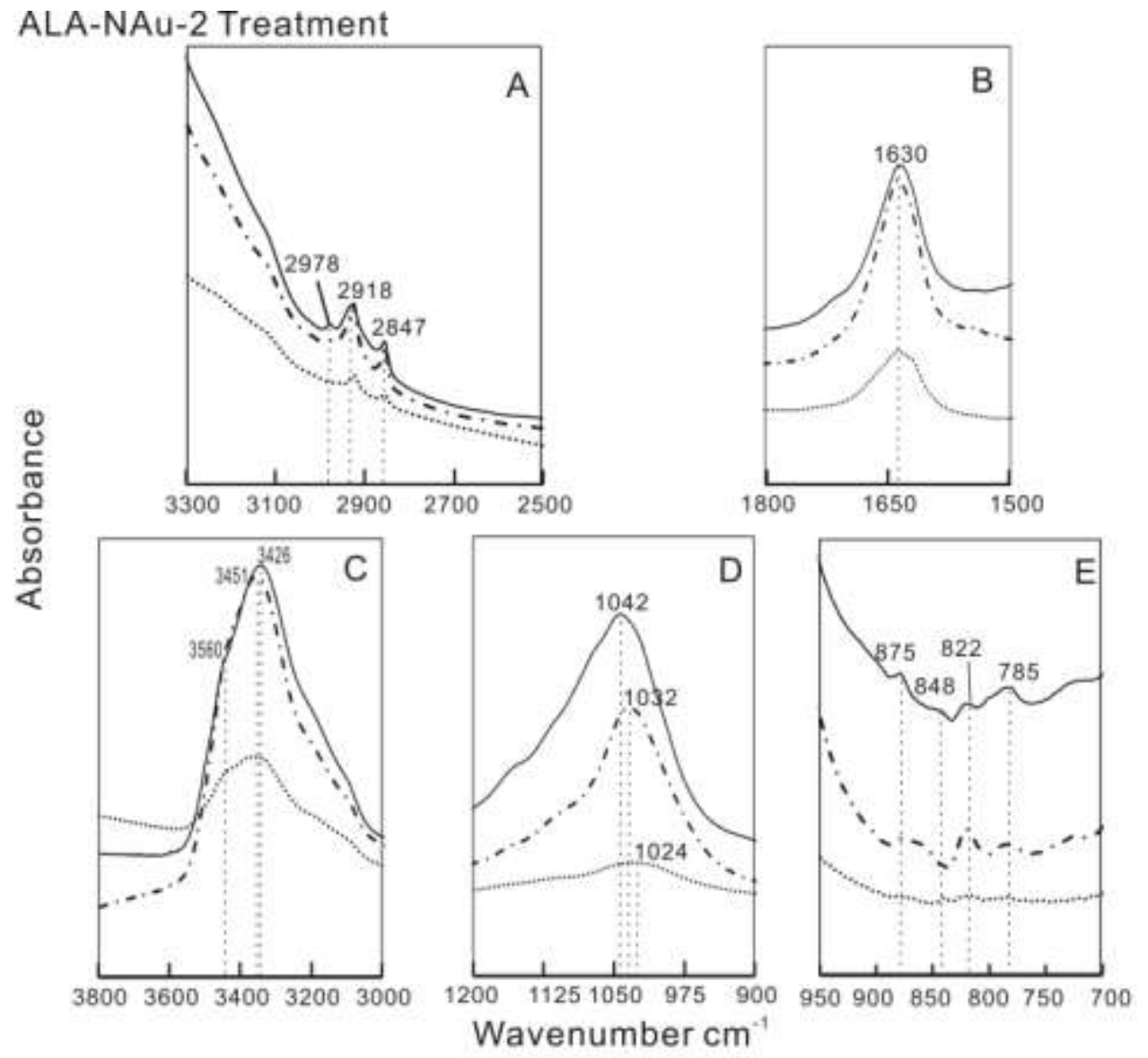

NAu-2 Treatment
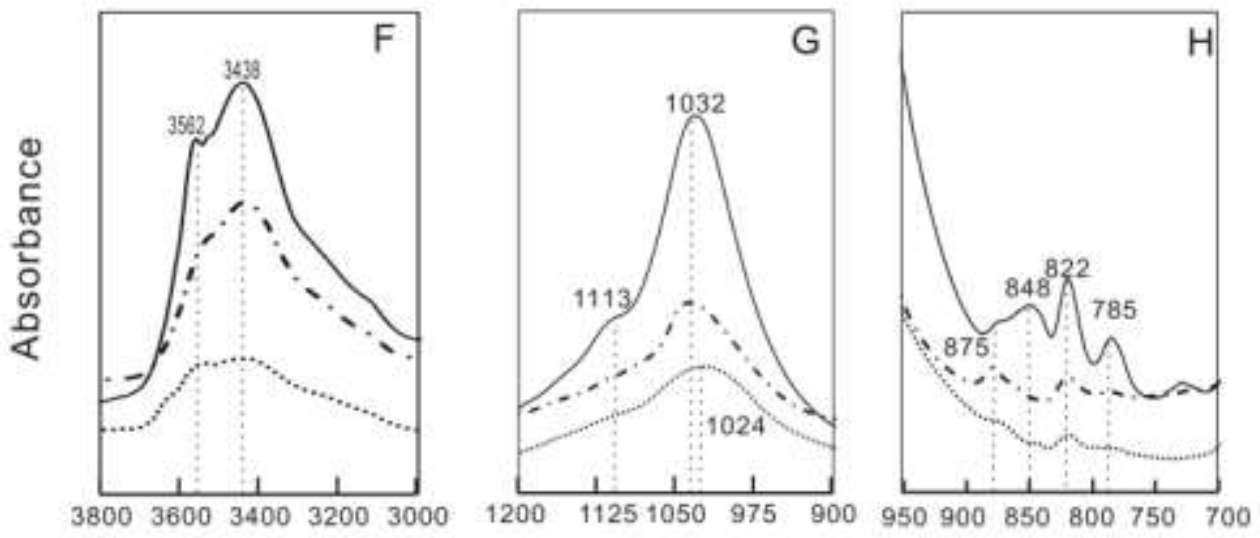

Wavenumber $\mathrm{cm}^{-1}$

Abiotic Control

Bioreduced Clay

DCB reduced Clay

Fig. 8 


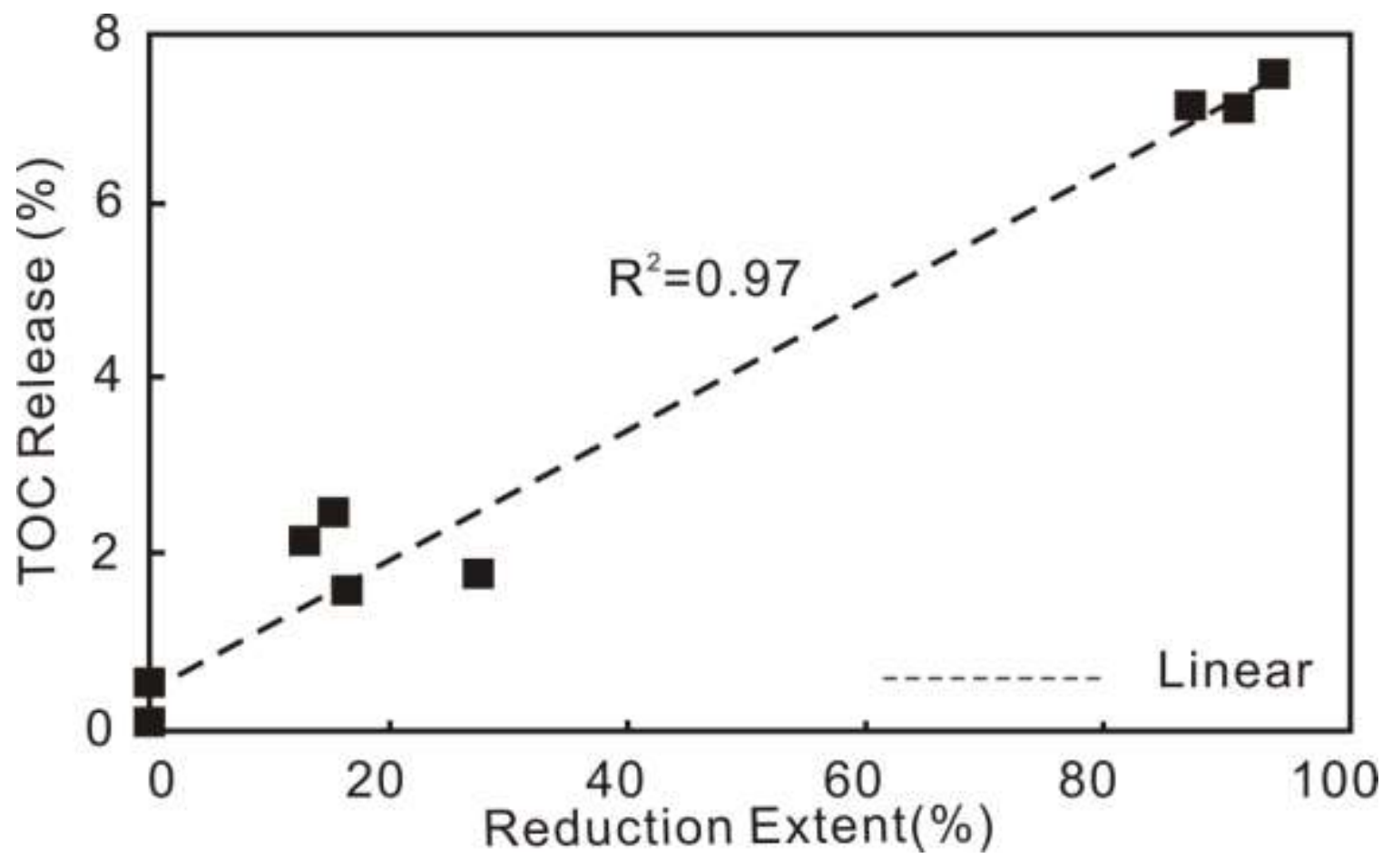

Fig. 9 